\title{
NIERACJONALNOŚĆ USANKCJONOWANA, CZYLI NAGRODA IMIENIA NOBLA W DZIEDZINIE EKONOMII DLA RICHARDA THALERA
}

ŚLĄSKI

PRZEGLĄD

STATYSTYCZNY

Nr 16(22)

ISSN 1644-6739

e-ISSN 2449-9765

DOI: $10.15611 /$ sps.2018.16.07

JEL Classification: A12, B31

\begin{abstract}
Streszczenie: Ekonomia behawioralna jest stosunkowo nowym nurtem, kwestionującym podstawę stosowanego w ekonomii neoklasycznej modelowania podmiotu działań ekonomicznych jako homo oeconomicus. Wykazując nieracjonalność w podejmowaniu decyzji przez ludzi, systematyczne błędy, jakimi obarczone jest ludzkie rozumowanie w określonych sytuacjach, oraz odczuwaną przez większość osób awersję do straty, Kahneman i Tversky zastąpili teorię użyteczności oczekiwanej teorią niepewnych perspektyw, dając asumpt do dalszych badań nad podejmowaniem decyzji przez rzeczywiste podmioty ekonomiczne. Richard Thaler, laureat Nagrody Nobla z dziedziny ekonomii z roku 2017, otrzymał to wyróżnienie w uznaniu zasług w rozwoju badań nad tymi zagadnieniami. W swoich pracach, opartych na eksperymentach laboratoryjnych oraz badaniach ankietowych, opisywał wiele interesujących efektów, w tym efekt posiadania czy mentalną rachunkowość.
\end{abstract}

Słowa kluczowe: ekonomia behawioralna, nieracjonalność, teoria niepewnych perspektyw, Richard Thaler.

Jeśli ktoś sądzi, że przeciętny człowiek nie zawsze podejmuje racjonalne decyzje, popełnia błędy w myśleniu, a nawet wówczas, gdy wie, jak powinien postąpić, miewa problemy z samokontrolą - niech czym prędzej kupuje bilet do Sztokholmu, bo 10 grudnia 2017 roku za tego typu konstatacje rozdają miliony.

Tegoroczny laureat, Richard Thaler, który wraz z medalem otrzymuje 9 milionów koron szwedzkich (ponad 3,8 miliona złotych wedle kursu z dnia otrzymania nagrody), wyróżniony został za wkład w ekonomię behawioralną, czyli dziedzinę, która - początkowo nienazwana - rozwijała się zasadniczo od zarania ekonomii jako nauki, a nawet i wcześniej. Paradygmat ekonomii neoklasycznej, może na fali kompleksów wobec bardziej matematyzowalnych dziedzin, operował pojęciem (nie)sławnego homo oeconomicus - istoty doskonale 
racjonalnej, podejmującej decyzje zgodnie $\mathrm{z}$ formalnymi modelami stworzonymi na papierze.

Ekonomia behawioralna, dla odmiany, wychodzi od innego punktu. Najpierw bada zachowania (czyli behawior) jednostek ludzkich jako podmiotów i aktorów działań ekonomicznych, a dopiero na podstawie tych obserwacji ewentualnie formułuje bardziej ogólne modele. Zamiast postrzegać człowieka takim, jakim być powinien (wedle dziwacznych kryteriów ekonomistów), przyjmuje go z całym dobrodziejstwem (czy przekleństwem) inwentarza. A immanentnym składnikiem naszego bagażu, zapakowanego nam przez ewolucję, jest właśnie brak ścisłej racjonalności i inne wybryki, sprzeciwiające się wzorcowi homo oeconomicus.

\section{Kłopoty z racjonalnością}

Prócz tego, co podpowiada choćby zdrowy rozsądek na temat stanu faktycznego, współczesna nauka pokazuje, iż doskonale racjonalny człowiek nie byłby w stanie efektywnie funkcjonować. Wręcz zagrożone byłoby jego biologiczne istnienie. Wiele - jeśli nie większość sytuacji z życia codziennego wymaga reakcji szybszych niż pozwoliłby na to stosowny namysł. W obliczu niebezpieczeństwa większość $\mathrm{z}$ nas reaguje instynktownie. Nawet jeśli trasa ucieczki przed tygrysem niekoniecznie jest optymalna, a dokładne obliczenia wskazałyby lepszą opcję, to wyciąganie laptopa i odpalanie programu obliczeniowego mogłoby dać efekty gorsze niż działanie podyktowane emocjami, czyli zwykłe zwiewanie, ile sił w nogach.

Zresztą, nie trzeba aż tygrysa, by dostrzec ułomność doskonałej racjonalności. Wystarczy owies i siano. To, które Aleksander Fredro dał osiołkowi w żłobie. Tego typu ośli dylemat, znany w literaturze jako paradoks osła Buridana, acz przywoływany już dużo wcześniej między innymi przez niezawodnego Arystotelesa czy jedenastowiecznego arabskiego uczonego al-Ghazaliego - miał ilustrować istnienie wolnej woli, choć współcześnie możemy go interpretować w kategoriach emocjonalności. Neurofizjolog Antonio Damasio relacjonował przypadek pacjenta z uszkodzeniem mózgu, które upośledziło emocjonalność mężczyzny, pozostawiając nietknięty iloraz inteligencji. Najprostsza czynność, którą przeciętny człowiek wykonuje bezmyślnie, kierując się kaprysem czy impulsem, dla opisywanego pacjenta stawała się skomplikowanym równaniem nie do rozwiązania. Czy zjeść na obiad pierogi czy kaszę z surówką? Każda osoba mogłaby 
zapewne wybrać lepszą opcję, kierując się swoim wiekiem, stanem zdrowia, zawartością minerałów we krwi i w obu proponowanych posiłkach, ale większość $\mathrm{z}$ nas dokonuje tego typu wyborów STATYSTYCZNY w mgnieniu oka, nie wykonując szczegółowych obliczeń. Ba, nie zdając sobie niemal sprawy, że nastąpił jakikolwiek proces decyzyjny. Konieczność racjonalnego kalkulowania najlepszej opcji w każdym, najdrobniejszym aspekcie życia zamieniłaby je w koszmar i uniemożliwiła normalne funkcjonowanie, o czym przekonał się pacjent Damasio. Większość $\mathrm{z}$ nas $\mathrm{w}$ ogóle nie przepada za podejmowaniem decyzji. Zapewne najbardziej znanym humanistą, poruszającym tę kwestię, był Erich Fromm ze swoją „Ucieczką od wolności”. W aspekcie bardziej ekonomicznym również nie zawsze lubimy czuć pełną kontrolę (i odpowiedzialność). Zwłaszcza że przeważnie chcemy myśleć o sobie jako o istocie (jednak) racjonalnej i dokonując wyboru, czujemy wewnętrzną presję, by dokonać go dobrze. Jednym z badaczy zajmujących się paradoksami takiej wolności jest Barry Schwartz, autor książki „Paradoks wyboru. Dlaczego więcej oznacza mniej” [Schwartz 2013]. Dla osoby stojącej przed bardzo szerokim wachlarzem opcji wybór dowolnej $\mathrm{z}$ nich związany jest $\mathrm{z}$ emocjonalnym kosztem odrzucenia wszystkich pozostałych, a im więcej opcji, tym mniej oczywisty wybór, tym większy koszt i tym trudniejsza decyzja. W efekcie niektórzy (zwłaszcza ci, którzy dążą do perfekcji, nie zadowalając się opcją dostatecznie dobrą w miejsce optymalnej) cierpią katusze oceniania przeszłych wyborów w kontekście innych odrzuconych wariantów. By tego uniknąć, mogą odwlekać moment dokonania decyzji, nie dokonując jej nigdy, pozbawiając się na przykład radości życia rodzinnego (do osiemdziesiątki pozostając stanu wolnego, wobec możliwości pojawienia się w przyszłości jeszcze lepszego kandydata czy kandydatki na współmałżonka).

Różnego rodzaju drogi na skróty - czy to działania instynktowne (strach), czy podążanie za kaprysem (na przykład w wyborze dania obiadowego), czy też w końcu dawanie posłuchu emocjom (choćby zakochaniu) - umożliwia nam funkcjonowanie w otaczającym nas świecie na w miarę satysfakcjonującym poziomie. Rzecz jasna, zarówno instynkt, jak i emocje mogą zaprowadzić na manowce i narazić na poważne problemy, jednakże, w obliczu alternatywny upiornie nieefektywnej racjonalności, są one opcją, paradoksalnie, bardziej racjonalną - jeśli za kryterium przyjąć postępowanie służące przetrwaniu i odniesieniu sukcesu reprodukcyjnego wedle logiki ewolucyjnej. 
Nawet wówczas, gdy świadomie staramy się przeprowadzać racjonalny proces decyzyjny, narażeni jesteśmy na liczne zasadzki, jakie zastawia na nas nasz własny umysł. Oczywiście, nie działa on przeciwko nam; tylko w warstwie językowej można oddzielić umysł od jego „posiadacza”. Jednakże skróty mentalne, które przeważnie dobrze nam służą - ale nie zawsze - są tak zakorzenione w naszej konstrukcji, że trudno je kontrolować nawet największym wysiłkiem rozumu. Te najrozmaitsze ,pułapki myślenia” znakomicie opisał jeden z pierwszych ich badaczy i laureat Nagrody imienia Nobla w dziedzinie ekonomii z 2002 roku Daniel Kahneman [Kahneman 2012].

Koniec końców, gdybyśmy nawet powściągnęli emocje i zdali się na racjonalność, gdyby nawet racjonalność nas nie zawiodła, czyli udałoby się nam uniknąć wszelkich pułapek popychających nas ku logicznym rafom: jak często wiedza, co jest dla nas najlepsze, powstrzymuje nas od działań z nią sprzecznych? Czy żaden z nałogowych palaczy nie słyszał o chorobach płuc, a żaden łakomczuch z nadwagą, sięgający po kolejne ciastko, nie miewa wyrzutów sumienia już w samym momencie sięgania po słodycze?

Wobec tego wszystkiego, co podpowiada nam obserwacja samych siebie i bliźnich, mądrość starożytna i współczesna nauka, wydaje się, iż sprawą zasadniejszą niż kwestia, kto po raz pierwszy podał w wątpliwość rozsądek w postępowaniu człowieka, jest pytanie, komu i kiedy w ogóle przyszło do głowy, iż jest ono zasadniczo racjonalne?

\section{Narodziny homo oeconomicus}

W chwili przyjścia na świat homo oeconomicus, jak każdy bobas, był jeszcze postacią nie do końca uformowaną, bez tej wyrazistości i ostrości, dla której z czasem jedni go pokochali, a inni znienawidzili. W gruncie rzeczy sam fakt jego narodzin był kwestią sporną, bo akt urodzenia sformułowany był niejasno.

Choć John Stuart Mill nigdy nie użył sformułowania homo oeconomicus (ani nawet jego odpowiednika w języku angielskim, w którym pisał), to właśnie jemu powszechnie przypisuje się ojcostwo tego kontrowersyjnego osobnika. A przecież twór, powołany do życia przez Milla, ani nie był wcale takim jednowymiarowym hiperracjonalnym konsumentem, jak późniejszy h.o., ani nawet Mill nie upierał się, iż on realnie istnieje. Ni mniej, ni więcej, stwierdzał tylko, iż „ekonomia polityczna nie zajmuje się człowiekiem jako całością ani tym, w jaki sposób działa on w społeczności. Jest nim zainteresowana 
tylko jako istotą pragnącą posiadania bogactwa, będącą w stanie porównywać efektywność środków prowadzących do tego celu (...) Abstrahuje od wszelkich pasji i motywów oprócz tych, które mogą przeSTATYSTYCZNY ciwstawiać się pragnieniu bogactwa, czyli niechęci do pracy czy pragnieniu natychmiastowej przyjemności" [Mill 1966]. A więc jednak: bierze pod uwagę takie nieracjonalne impulsy, które dwudziestowieczny oeconomicus uznałby zapewne za uwłaczające jego reputacji. Później z kolei Mill wskazuje na potrzebę reprodukcji, jako kolejny motyw, który trzeba uwzględnić w analizie zachowań człowieka, nawet w ekonomicznym ich aspekcie.

Dążenia do bogactwa, przyjemności, odpoczynku i posiadania potomstwa - człowiek ekonomiczny w ujęciu Milla jest nieco mniej monotematyczny niż jego późniejsza karykatura. Choć i tak nie uchroniło go to od ataków. Już jemu współczesny John Kells Ingram, który nota bene po raz pierwszy użył określenia ,,człowiek ekonomiczny" (economic man), szydził z ekonomii politycznej Milla, powiadając, iż „nie zajmuje się ona rzeczywistymi ludźmi, ale urojonymi »ludźmi ekonomicznymi«, pojmowanymi jako »pieniędzorobne zwierzęta «" [Ingram 1888, s. 218] (thum. aut.).

Pomimo tej wczesnej krytyki, racjonalny konsument stopniowo przecierał sobie ścieżkę do głównego nurtu ekonomii. Im więcej matematyki było w tej dziedzinie, tym bardziej chciało się ujmować zachowania ludzkie $\mathrm{w}$ jakieś równania. A im prostsze równanie, tym bardziej eleganckie wydawało się taki ujęcie.

Zdobycie terytorium przez ten inwazyjny gatunek odbyło się niemal cichaczem, bo mało kto ośmieliłby się twierdzić, iż charakterystyka homo oeconomicus to opis realnej natury ludzkiej. Zwykle zasłaniano się dwoma zastrzeżeniami, często łączonymi. Przeważnie, jak Mill, przedstawiano modelowego człowieka jako model właśnie użyteczny tylko do celów ilościowego ujęcia ekonomii. Znaczne uproszczenia w modelowaniu obiektów badań nie są wymysłem tylko ekonomistów. Cytując Alberta Einsteina: „Wszystko należy upraszczać, jak tylko można". I tak, na przykład, traktowanie cząstek gazu jako nierozróżnialnych punktów materialnych pozwoliło sformułować bardzo użyteczne równanie stanu gazu doskonałego. Jeśli założenia prowadzą do trafnych przewidywań, kogo obchodzi jakiś metafizyczny status tych założeń? Skoro światło porusza się tak, jakby minimalizowało swoje działanie, a zwierzęta zachowują sie tak, jakby maksymalizowały prawdopodobieństwo swojego sukcesu reprodukcyjnego, kto będzie zgłaszał sprzeciw, że fotony z pewnością nie mogą podejmo- 
wać świadomych decyzji (a zwierzęta raczej tego nie robią, przynajmniej nie w aspekcie długofalowych strategii ewolucyjnych)? Milton Friedman w „Esejach z zakresu ekonomii pozytywnej” pisał: „(...) właściwym pytaniem dotyczącym »założeń« teorii nie jest to, czy są one »realistyczne«, gdyż nigdy nie są, ale, czy są wystarczająco dobrym przybliżeniem dla określonego celu" [Friedman 1953, s. 15] (podkreślenie aut.). W innym miejscu Friedman wyjaśnia, iż jakikolwiek byłby mechanizmy zachowania biznesmena jako racjonalnego maksymalizatora zysku - świadomy zamysł, przypadek czy intuicja dopóki zachowuje się on $\mathrm{w}$ ten sposób, dopóty funkcjonuje; w przeciwnym przypadku siły rynkowe usuną go z gry.

Drugi rodzaj prób legitymizacji homo oeconomicus był bardziej wyrafinowany, acz niesprzeczny z poprzednim rozwiązaniem. Sugerował on, iż rzeczywistość ekonomiczna i rynki działają tak, że wszystkie inne cechy ludzkie, poza tymi „oeconomicusowymi”, pozostają w kontekście zachowań rynkowych niewidoczne. Wbrew pozorom, jest to całkiem głębokie stwierdzenie, w duchu niewidzialnej ręki Adama Smitha. Tak jak partykularne egoizmy u szkockiego filozofa dążyły, we wspólnym tańcu, do wzajemnego dobra, tak i irracjonalności ludzkie miały dawać w rezultacie rynkowej współgry imitację racjonalnych wyborów, à la homo oeconomicus.

Tak czy owak uzasadniane, założenie o racjonalności leżało w sercu kluczowych teorii współczesnej ekonomii neoklasycznej, na przykład teorii równowagi ogólnej. Niektórzy posuwali się nawet do konstatacji: optymalizacja + równowaga $=$ ekonomia

Rozpanoszyła się koncepcja podmiotu-maksymalizatora, potrafiącego przywidywać efekty swoich działań i dążącego do największej możliwej własnej użyteczności. Jak to ujmuje E. Roy Weintraub [2002], ekonomia neoklasyczna zdefiniowana jest przez trzy założenia: 1) ludzie mają racjonalne preferencje; 2) ludzie maksymalizują użyteczność, a firmy zyski; 3) ludzie działają niezależnie, opierając się na pełnej informacji.

Racjonalność preferencji oznacza zasadniczo ich kompletność i przechodniość, co będzie bardziej szczegółowo omówione w kontekście teorii użyteczności. Jeśli jednakże kiedykolwiek zirytowało was pytanie typu: czy wolelibyście stracić lewą nogę czy prawe oko, rozumiecie, jakich problemów nastręcza to beztroskie założenie. Również pełna informacja w oczywisty sposób jest w wielu przypadkach jeśli nie $\mathrm{w}$ większości $\mathrm{z}$ nich - problematyczna. Pomyślmy o tych wszystkich mężczyznach, którzy przed wypowiedzeniem sakramen- 
talnego „tak” nie brali pod uwagę, że pół roku później wprowadzi się teściowa. Uzupełnieniem założenia o pełnej informacji bywa częstokroć idea uczenia się na błędach popełnianych w przeszłości (teoria STATYSTYCZNY racjonalnych oczekiwań), co świetnie egzemplifikują liczne żony pijaków wierzące, że tym razem to $\mathrm{n}$ a p r a w d ę ostatni raz.

Jeśli chodzi o maksymalizację, we współczesnej teorii konsumpcji zakłada się, iż ludzie tak wydatkują swoje dochody, by zoptymalizować jakość życia nie tylko w okresie bieżącym (co postulował Keynes), ale długofalowo, w ciągu całego życia, a może nawet biorą pod uwagę dobrobyt spadkobierców (hipoteza dochodu permanentnego M. Friedmana i hipoteza cyklu życia F. Modiglianiego). Wbrew takim teoriom, już w dawnych czasach każdy właściciel szynku dobrze wiedział, że jego klientela będzie bardzie liczna w dzień wypłaty, co jest raczej niezbyt długofalowym planowaniem.

Elegancja matematyczna, jaką udawało się uzyskać w ekonomii dzięki upraszczającym założeniom, przez dłuższy czas stanowiła wystarczające usprawiedliwienie tych symplifikacji. W pewnym momencie jednakże coraz więcej badaczy zaczęło mieć wątpliwości już nie tylko odnośnie do prawdziwości założeń, ale i uzyskiwanych dzięki nim wyników. Przytaczając w całości cytowane powiedzenie Einsteina: „Wszystko należy upraszczać, jak tylko można. Ale nie bardziej”.

Z czasem standard modelowania zachowań ekonomicznych począł ewoluować.

Na pierwszy ogień, jeszcze nawet przed uformowaniem się paradygmatu neoklasycznego, poszło pojęcie maksymalizacji.

Wszystko zaczęło się w dawnych czasach, gdy rachunek prawdopodobieństwa służył głównie co bardziej świattym hazardzistom do obliczania ich szans w danej grze. Powstało wówczas domniemanie, iż słuszną strategią jest postępowanie takie, które maksymalizuje wartość oczekiwaną.

\section{Wartość oczekiwana...}

W którą z dwóch gier wolelibyście zagrać? W grze pierwszej z prawdopodobieństwem $25 \%$ wygrać można tysiąc złotych, a z prawdopodobieństwem $75 \%$ wygrać można pięć tysięcy. $Z$ kolei w drugiej grze z prawdopodobieństwem $50 \%$ wygrać można trzy tysiące złotych, a z prawdopodobieństwem $50 \%$ - cztery tysiące.

Jeśli wasz wybór jest zgodny z wyborem sporej większości, zdecydowaliście się na grę pierwszą. Jeśli dodatkowo macie dryg do 
przeprowadzania rachunków, mogliście ten wybór uzasadnić następującym wyliczeniem. W grze pierwszej:

$$
0,25 \cdot 1+0,75 \cdot 5=4
$$

a w grze drugiej:

$$
0,5 \cdot 3+0,5 \cdot 4=3,5
$$

co jest wartością mniejszą niż dla gry pierwszej.

Jeśli taki był tok waszego rozumowania, to posłużyliście się tym, co fachowo nazywa się wartością oczekiwaną loterii, i wybieraliście tę z dwóch gier, dla których wartość oczekiwana jest korzystniejsza.

Na pierwszy rzut oka opieranie się na tak skalkulowanej wielkości ma spory sens. Hazardziści odruchowo wręcz posługują się podobnymi rachubami. Szybko jednak można zauważyć ograniczenia tej metody. Historycznym przykładem jest sformułowany przez Mikołaja Bernoullego i opublikowany przez jego kuzyna Daniela Bernoullego w 1738 roku na łamach periodyku Akademii Petersburskiej tak zwany paradoks petersburski.

Zastanówcie się, ile bylibyście skłonni zapłacić za dopuszczenie do udziału w następującej grze: prowadzący rzuca monetą aż do momentu wyrzucenia pierwszego orła. Jeśli orzeł wypadnie za pierwszym razem, otrzymujecie dwa złote. Jeśli za drugim razem - cztery. W przypadku dwóch reszek, a następnie orła otrzymujecie osiem złotych. I tak dalej, za każdym rzutem, którego rezultatem jest reszka, wasza potencjalna końcowa wygrana ulega podwojeniu.

Może na pierwszy rzut oka gra nie wygląda specjalnie atrakcyjnie, ale jeśli policzymy oczekiwaną wygraną, okaże się ona... nieskończona! Bo faktycznie, mamy $1 / 2$ szansy na wygranie 2 złotych, 1/4 na wygranie 4 złotych i tak dalej, z prawdopodobieństwem $(1 / 2)^{n}$ wygrywamy sumę $2^{n}$. Zatem wartość oczekiwana wynosi:

$$
\frac{1}{2} \cdot 2+\frac{1}{4} \cdot 4+\frac{1}{8} \cdot 8+\cdots+\frac{1}{2^{n}} \cdot 2^{n}+\cdots=1+1+1+\cdots+1+\cdots,
$$

a że nie istnieje górne ograniczenie - teoretycznie orzeł może wypaść po raz pierwszy dopiero za setnym, milionowym czy miliardowym razem - oczekiwana wygrana jest nieskończona!

Zatem, ile bylibyście skłonni zapłacić za dopuszczenie do udziału w tej grze? Gdybyście kierowali się tylko oczekiwaną wysokością wygranej, zaryzykowalibyście każdą sumę mniejszą od tej wartości, czyli w przypadku gry petersburskiej - po prostu każdą skończoną sumę! 
Jeśli coś wam tu nie pasuje, nie jesteście w tym osamotnieni. Ten bunt intuicji przeciwko wyciągniętemu na podstawie prawdopodobieństw wnioskowi jest przyczyną, dla której opisany problem nazwany został paradoksem. Paradoksem jest jednak tylko z punktu widzenia zakładającego, że mielibyśmy kierować się wartością oczekiwaną. Ale przecież fakt, że taka strategia sprawdza się w przypadku prostej sytuacji, opisanej wcześniej, wcale jeszcze nie oznacza, że należałoby podnieść ją do rangi ogólnie obowiązującej.

Gdyby można grać w petersburską grę tyle razy, ile by się chciało (i gdyby mieć odpowiednio długie życie), można by się zgodzić zapłacić za ten przywilej dowolną kwotę, mając pewność, że w końcu się zwróci. Jeśli jednakże ma się tylko jedno podejście do gry, już dziesięć złotych wydaje się zapewne ceną zbyt wygórowaną. W końcu miałoby się tylko $12,5 \%$ szansy na to, że inwestycja się zwróci. W takich warunkach trudno doprawdy uznać decyzję o nieprzystąpieniu do gry za nieracjonalną.

Aby uniknąć nieracjonalnych wniosków dotyczących ludzkiej racjonalności, Daniel Bernoulli użył pojęcia emolumentum („korzyści”, „zysku”) z loterii, niebędącego równoważnym wartości pieniężnej.

Trudno ocenić, czy pomysł ten bardziej zasługuje na miano rewolucyjnego, czy całkowicie trywialnego. Być może, z jednej strony, jest trywialnie oczywisty, z drugiej - rewolucyjnym krokiem było wprowadzenie ,zdrowego rozsądku” i subiektywnych ocen do matematyki.

Aby uświadomić sobie różnicę pomiędzy wartością pieniężną a wartością subiektywną, wystarczy wyobrazić sobie pustelnika, który dysponuje skromnymi środkami pozwalającymi tylko i wyłącznie na podtrzymanie biologicznego istnienia, i który niczego więcej nie potrzebuje, a wręcz odrzuca. Jaką wartość ma dla niego najmniejszy dodatek? Żadnej, jakakolwiek by nie była jego wartość pieniężna, gdyż i tak nie zrobi z niego użytku, hołdując wybranemu przez siebie stylowi życia. Jaką wartość ma dla niego każdy okruch istniejącego dobytku? Nieskończoną, gdyż, jak powiedziano, jego zasoby mają graniczny poziom, poniżej którego niemożliwe jest przeżycie.

Poza wszystkim, mamy tylko jedno życie.

Co ma to dość oczywiste stwierdzenie z teorią wartości oczekiwanej? Otóż, wartość oczekiwana to spodziewana średnia wypłata $\mathrm{w}$ grze (czy jakimkolwiek działaniu) powtarzanej nieskończenie wiele razy. (Wystarczy wspomnieć, że wartość oczekiwana w rzucie kostką do gry wynosi 3,5 - czy ktokolwiek o zdrowych zmysłach oczekuje, że taka właśnie liczba oczek wypadnie w pojedynczym rzucie?). Nie- 
skończenie wiele, to raczej dużo. Statystycy wiedzą jednak, że różne graniczne wartości osiągane są z dużą dokładnością już przy dostatecznie wielu powtórzeniach, niekoniecznie nieskończenie wielu. O ile zatem biznesmen latający samolotem raz w tygodniu może uznać za racjonalne - na mocy obliczenia wartości oczekiwanej - ubezpieczanie swego bagażu (pod warunkiem odpowiednich stawek do zapłacenia), o tyle, podejmując jednorazowe wybory życiowe, na mocy czego właściwie mielibyśmy kierować się wartością, której oczekiwalibyśmy przy nieskończonej liczbie powtórzeń? Czy naprawdę istnieje tu jakikolwiek logiczny związek? Czy raczej przypomina to obstawianie 3,5 dla rzutu monetą?

\section{...użyteczność oczekiwana...}

Wygląda na to, że krok wykonany przez Daniela Bernoullego (oraz przez innych badaczy i przed nim, i po nim), stanowił rozsądny ruch w kierunku uwiarygodnienia opisu zachowania ludzkiego. Choć różniące się $\mathrm{w}$ wielu szczegółach teorie oczekiwanej użyteczności, w przeciwieństwie do teorii oczekiwanej wartości, biorą bowiem pod uwagę nie tylko rynkowy wymiar obliczonej spodziewanej wypłaty $\mathrm{z}$ danego działania. $\mathrm{W}$ ten sposób uniknąć możemy imputowania nieracjonalności osobie, która, całkowicie chyba jednak rozsądnie, nie godzi się na wystawianie na niewielkie ryzyko własnego życia, nawet mając szansę wygrać $\mathrm{w}$ ten sposób fortunę. Za jaką kwotę bylibyście skłonni zagrać w rosyjską ruletkę? Czy wszyscy ci, którzy w ogóle nie biorą pod uwagę takiej opcji, faktycznie są irracjonalni?

Użyteczność, na szczęście, nie jest równoważna z rynkową wartością wymienną. Dzięki temu możemy przypisać własnemu życiu wysoką użyteczność (dla nas samych przynajmniej) i w ten sposób wykaraskać się z zarzutu nieracjonalności. Możemy w ten sposób uwzględnić również fakt, że tysiąc złotych dla osoby ubogiej ma inne znaczenie (na przykład, opłacenie dwumiesięcznego czynszu i uniknięcie eksmisji) niż ten sam tysiąc dla milionera (większe napiwki dla manicurzystki?).

Spośród różnych postaci teorii oczekiwanej użyteczności największą popularność zyskała aksjomatyczna teoria autorstwa von Neumanna i Morgensterna, ogłoszona w 1944 roku. Przez kilka dekad dość powszechnie uważano zarówno, iż racjonalny człowiek powinien zachowywać się zgodnie z tą teorią, jak i - że tak właśnie się zachowuje. Postawy odbiegające od tego wzorca postrzegane były jako 
anomalie. Innymi słowy, teoria oczekiwanej użyteczności uważana była za teorię zarówno normatywną (jak być powinno), jak i deskryp- ${ }_{\mathrm{Nr} \text { 16(22) }}$ tywną (jak jest w rzeczywistości).

Niestety, gdyby przeciętny człowiek świadom był surowych restrykcji, narzucanych mu przez von Neumanna i Morgensterna, prędko mógłby popaść w kompleksy. Uważny obserwator łatwo mógłby bowiem dostrzec, że, pomijając kwestię pobożnych życzeń, zachowania ludzkie częstokroć przeczą aksjomatom, i nie jest to specyfiką jakiegoś marginesu ludzi niewykształconych czy niepełnosprawnych intelektualnie.

Zacznijmy od najprostszego z aksjomatów, czyli aksjomatu kompletności i przechodniości, o którym była już mowa. Mówi on w zasadzie tylko tyle, że osoba potrafi porównać każde dwie loterie, jakie ma do wyboru. Trywialnie oczywiste, nieprawdaż? Proszę zatem wybrać: wolelibyście 25-procentowe ryzyko utraty oka w zamian za $75 \%$ szansy na wygranie miliona bądź też $17 \%$ ryzyka zachorowania na nowotwór nerki w zamian za $83 \%$ szansy na otrzymanie Nagrody Nobla? Nie potraficie zdecydować? To może spróbujmy z innym z aksjomatów. Wolicie jabłka czy gruszki? Gruszki czy śliwki? Śliwki czy melony? Melony czy jabłka? Niemal każdy, postawiony przed sekwencją tego typu wyborów, jeśli zestawień par jest dostatecznie wiele, popada w końcu w jakąś sprzeczność. Okazuje się, na przykład, że woli jabłka od gruszek, gruszki od śliwek, ale śliwki woli od jabłek. Sądzicie, że wy akurat uniknęlibyście pogwałcenia aksjomatu przechodniości preferencji? Spróbujcie zatem wybrać spośród następujących dwóch loterii. W jednej z nich, nazwijmy ją loterią $\mathrm{A}$, macie pewność wygrania miliona, w drugiej, loterii $\mathrm{B}-10 \%$ na wygranie 5 milionów, $89 \%$ na wygranie miliona i $1 \%$ na zostanie $\mathrm{z}$ pustymi rękoma. Wybraliście? Zatem następna para loterii. W jednej z nich, loterii $\mathrm{C}$, macie $11 \%$ szans na wygranie miliona i $89 \%$ na zostanie z niczym. W drugiej loterii, $\mathrm{D}$, z prawdopodobieństwem $10 \%$ wygrywacie 5 milionów, a z prawdopodobieństwem 90\% - nic. Dokonaliście wyboru?

Może jesteście z siebie dumni, że tym razem z łatwością dokonaliście obydwu wyborów, zatem sprawdzian z aksjomatu kompletności został zdany śpiewająco. Jeśli jesteście podobni do większości ludzi, w pierwszym przypadku spośród loterii A i B wybraliście A, natomiast $\mathrm{w}$ drugim - preferowaliście $\mathrm{D}$ ponad $\mathrm{C}$.

I tu właśnie spotykamy się z laureatem Nagrody imienia Nobla z dziedziny ekonomii z roku 1988, Mauricem Allaisem. 


\section{ŚLĄSKI \\ PRZEGLĄD \\ STATYSTYCZNY \\ Nr 16(22) \\ ...paradoks Allaisa...}

W artykule z 1953 roku Maurice Allais przedstawił opisane powyżej dwie pary loterii wraz z wyborami większości badanych przez niego respondentów. Jeśli nawet podjęlibyście inną decyzję, trudno zbyć wybory większości stwierdzeniem, iż nie znają się oni na rzeczy i decydują źle. O ile bowiem nie uznamy, że nasze określenie gatunkowe, sapiens, odnosi się tylko do mniejszości, a i modele ekonomiczne ograniczać się mają do tej elity, pozostanie pytanie, w jakie ramy ująć zachowania sporej części populacji.

Ale właściwie cóż takiego dziwnego jest w wyborze loterii A oraz loterii D? - można zapytać. Owszem, wartość oczekiwana loterii $\mathrm{B}$ jest większa niż loterii A, ale już argumentowaliśmy, że wcale nie jest nieracjonalne kierowanie się czymś innym niż wartością oczekiwaną.

Paradoks - bo takie miano i jego nazwisko otrzymał zaobserwowany przez francuskiego naukowca efekt - polega na zestawieniu wyborów $\mathrm{w}$ dwóch parach loterii. $\mathrm{Z}$ punktu widzenia oczekiwanej użyteczności wybory A i D nie są spójne, a dokładniej mówiąc gwałcą aksjomat niezależności (od nieistotnych alternatyw). W skrócie: jeśli w pierwszym przypadku rezygnujecie z szansy na pięć milionów, by uniknąć jednego procenta ryzyka zostania z niczym (czyli wybieracie loterię A), w drugiej parze loterii takie same preferencje spowodowałyby, że jednoprocentowy wzrost ryzyka pozostania z pustymi rękoma powinien przeważyć szalę na rzecz loterii C. Zatem: A i C albo B i D, inaczej wybory nie są spójne z punktu widzenia teorii użyteczności oczekiwanej.

Formalnie, zgodnie z teorią, użyteczności oczekiwane loterii można zapisać następująco:

$$
\begin{gathered}
U(A)=U(1 \mathrm{mln}) ; \\
U(B)=0.10 U(5 \mathrm{mln})+0.89 U(1 \mathrm{mln})+0.01 U(0) ; \\
U(C)=0.11 U(1 \mathrm{mln})+0.89 U(0) ; \\
U(D)=0.10 U(5 \mathrm{mln})+0.90 U(0) .
\end{gathered}
$$

Zwróćmy uwagę, że wychodzimy tu poza teorię wartości oczekiwanej, bo wcale nie zakładamy, na przykład, że użyteczność pięciu milionów jest większa niż użyteczność jednego miliona (co wynikałoby z wielkości kwot): oznaczamy je po prostu symbolami $U(5 \mathrm{mln})$ oraz $U(1 \mathrm{mln})$. 
Teoria mówi, że skoro dana osoba woli loterię A niż B, oczekiwaz czego wynika, że:

$$
U(1 \mathrm{mln})>0.1 U(5 \mathrm{mln})+0.89 U(1 \mathrm{mln})+0.01 U(0),
$$

a po przekształceniu:

$$
0.11 U(1 \mathrm{mln})>0.10 U(5 \mathrm{mln})+0.01 U(0) .(*)
$$

Na mocy tej samej zasady przedkładanie loterii D nad C oznacza:

$$
0.10 U(5 \mathrm{mln})+0.90 U(0)>0.11 U(1 \mathrm{mln})+0.89 U(0),
$$

a zatem:

$$
0.10 U(5 \mathrm{mln})+0.01 U(0)>0.11 U(1 \mathrm{mln}) .(* *)
$$

Jak widać, w obu nierównościach, (*) i (**), występują te same wyrażenia, ale znak pomiędzy nimi jest odwrotny! Otrzymujemy zatem sprzeczność i dowód na to, że z teorią von Neumana i Morgensterna jest coś nie tak, przynajmniej jeśli chodzi o większość populacji.

Co zatem może szwankować w przedstawionej powyżej rekonstrukcji rozumowania, mającego leżeć u podłoża naszych decyzji?

\section{...i teoria niepewnych perspektyw}

$\mathrm{Na}$ pierwszy rzut oka widać, że w rozumowaniu prowadzącym do paradoksu Allaisa łatwo zakwestionować można dwa elementy. Po pierwsze, sam status wielkości oczekiwanej, co podnoszone było już w kontekście wartości oczekiwanej. Z definicji są to wartości średnie otrzymywane przy nieskończonej sekwencji powtórzeń tej samej gry czy wydarzenia. My zazwyczaj mamy do czynienia $\mathrm{z}$ jednokrotnie przeżywanym życiem, a jeśli chodzi o wydarzenia w nim zachodzące - im donioślejsze, tym rzadziej, zasadniczo, są powtarzane. Cokolwiek myśleliby o tym matematycy czy statystycy, nawykli do operowania (na kartce papieru) nieskończonymi liczbami powtórzeń, jak nakłonić kogoś do zaryzykowania własnego życia, argumentując, iż podejmowane nieskończenie wiele razy ryzyko to jest $\mathrm{z}$ pewnością opłacalne? Większy sens miałoby prezentowanie takich wyliczeń decydentowi zarządzającemu żywotami milionów ludzi, do żadnego z nich niemającemu szczególnej predylekcji.

Po drugie, aby uzyskać sprzeczność pomiędzy nierównościami $(*)$ i $(* *)$, dokonywaliśmy pewnych operacji na użytecznościach. O ile 
przenoszenie $\mathrm{z}$ jednej na drugą stronę może wydawać się mało kontrowersyjne, o tyle już odejmowanie 89\% użyteczności „,niczego” od 90\% użyteczności tegoż, może być kwestionowalne. Dlaczego? Choćby nie wiadomo, jak bardzo argumentować, iż jest to nieracjonalne, większość osób widzi różnicę pomiędzy skokiem od $0 \%$ do $1 \%$ a zmianą od $89 \%$ do $90 \%$. Czy faktycznie w jakiś fundamentalny sposób gwałci to reguły rozsądku (racjonalności)? Dlaczego wartość bezwzględna zmiany, wynosząca w obu przypadkach tyle samo, czyli jeden punkt procentowy, ma mieć większe znaczenie niż zmiana względna, oznaczająca wzrost o nieco ponad $1.1 \%(1 / 89 \approx 0.011)$ lub wzrost o procent... nieskończony $(1 / 0 \rightarrow \infty)$ ? Kto zadekretował, że bardziej racjonalne jest branie pod uwagę zmian bezwzględnych? Nasze zmysły, na przykład, rejestrują zazwyczaj nie to, o ile bodziec się zmienił, ale raczej, ile razy wzrósł lub zmalał (prawo Webera-Fechnera).

Rezygnacja z „obiektywnych” prawdopodobieństw oraz z brania pod uwagę jedynie zmian bezwzględnych to jedne z głównych przesłanek teorii niepewnych perspektyw, zaproponowanej w 1979 roku przez Daniela Kahnemana i Amosa Tverskiego [Kahneman, Tversky 1979].

Jako psychologowie Kahneman i Tversky uznali - dość rozsądnie, jak się wydaje - że (w przypadku większości ludzi, z ekonomistami włącznie) procesy decyzyjne realizowane są z udziałem psychiki osoby decydującej, a nie na zewnętrznym dysku maszyny obliczeniowej. Dążąc zatem do stworzenia modelu $\mathrm{w}$ minimalnym choćby stopniu opisującym to, co jest (a nie tylko to, co chciałoby się, by było), nie można nie uwzględniać pewnych podstawowych uwarunkowań ludzkiego sposobu myślenia i reagowania. A nie da się zaprzeczyć - bo obserwowano to wielokrotnie zarówno $\mathrm{w}$ życiu codziennym, jak i warunkach laboratoryjnych, stworzonych $\mathrm{w}$ ramach uprawiania ekonomii behawioralnej - że większość ludzi cechuje awersja do ryzyka oraz że wszelkie oceny dokonywane są w odniesieniu do jakiegoś punktu odniesienia, którym może być stan istniejący bądź stan zasugerowany.

Zgrubny skrót teorii niepewnych perspektyw wedle Kahnemana i Tverskiego mógłby być zatem przedstawiony następująco. Przy podejmowaniu decyzji człowiek dokonuje najpierw wstępnej obróbki danych: ustala punkt odniesienia, pomija prawdopodobieństwa bardzo małe, nieproporcjonalnie wielką wagę przykładając do zdarzeń pewnych - a wszystko to odbywa się poniżej progu świadomości, przez co procesem tym można do pewnego stopnia manipulować. 
Dwa przykłady.

Jeśli opłata przy użyciu karty kredytowej jest wyższa niż przy płatności gotówką, czy oznacza to, że za użycie karty trzeba zapłacić STATYSTYCZNY więcej, czy też otrzymuje się zniżkę przy płatności gotówką? Różnica niby tylko semantyczna, ale wpływa wyraźnie na nastawienie konsumentów. Doskonale o tym wiedzą wydający karty kredytowe, którzy jakiś czas temu przeprowadzili w Stanach Zjednoczonych skuteczną batalię o zmianę ujęcia niezmiennego $\mathrm{w}$ swojej istocie faktu różnicy w wysokości opłat.

Nad kraj nadciąga epidemia śmiertelnej choroby. Wybralibyście strategię narodową A, która uratuje życie dokładnie $50 \%$ obywateli, czy strategię $B$, która $z$ prawdopodobieństwem $1 / 2$ uratuje wszystkich, a z prawdopodobieństwem $1 / 2$ nie uratuje nikogo? Druga alternatywa: strategia B, która poświęci 50\% ludności, czy strategia D, która z prawdopodobieństwem $1 / 2$ uratuje wszystkich, a z prawdopodobieństwem $1 / 2$ nie uratuje nikogo? Oczywiście, obie alternatywy są identyczne, bo strategie A i C są w istocie rzeczy takie same, różniąc się tylko ujęciem. Jednakże ta różnica w warstwie językowej może spowodować uzyskanie odmiennych odsetków odpowiedzi, gdyż w jednym przypadku kieruje się uwagę respondenta na szansę, a w drugiej - na ryzyko.

Nawet jeśli sami jesteście niewrażliwi na takie psychologiczne sztuczki, musicie przyjąć do wiadomości fakt, że większość ludzi jednak jest i każda teoria pretendująca do opisywania rzeczywistości musi to uwzględniać. Ludzie są emocjonalni. Osoby, którym się to nie podoba, niech zwrócą uwagę na to, że taka ich postawa to również reakcja emocjonalna.

\section{Ekonomia behawioralna i Richard Thaler}

Obecnie teoria niepewnych perspektyw jest znakomicie ugruntowana w głównym nurcie nauki, a jeden z jej ojców, Daniel Kahneman, otrzymał za jej sformułowanie Nagrodę imienia Nobla z dziedziny ekonomii w 2002 roku (współtwórca teorii, Amos Tversky, zmarł sześć lat przed decyzją Komitetu Noblowskiego). W roku 1980 jednakże minął zaledwie rok od publikacji pracy Kahnemana i Tverskiego, a obwieszczenie w artykule przez 35-letniego, nieznanego szerzej badacza, iż „W pewnych określonych sytuacjach wielu konsumentów zachowuje się w sposób niezgodny z teorią ekonomiczną" [Thaler 1980] mogło być uważane za akt niemałej odwagi. Thaler miał w tym jednak wsparcie, psychiczne i merytoryczne, nie byle kogo, bo same- 
go Kahnemana, którego poznał na Uniwersytecie Stanforda i z którym od kilku lat odbywał długie dyskusje w trakcie spacerów.

Richard Thaler pochodzi z inteligenckiej rodziny o korzeniach $\mathrm{w}$ Brzeżanach (obecnie na Ukrainie). Po dzieciństwie spędzonym w stanie New Jersey szlify akademickie - dyplom odpowiadający polskiemu magisterium oraz doktorat - zdobywał na Uniwersytecie w Rochester. Tam właśnie, przy okazji pisania rozprawy doktorskiej, po raz pierwszy zainteresował się problemami, które po latach miały go zaprowadzić na spotkanie z Karolem Gustawem Bernadottem.

Ile bylibyście skłonni zapłacić, by zredukować ryzyko natychmiastowej śmierci o jedną część na tysiąc? (Tak, takie ryzyko zawsze istnieje! Pomyślcie tylko o spadających fragmentach satelitów czy nagłym zatrzymaniu krążenia!). A za jaką zapłatę bylibyście skłonni wziąć udział w eksperymencie, w którym jeden uczestnik na tysiąc umiera?

W ramach pracy doktorskiej Thaler usiłował wyliczyć, ile kosztuje ludzkie życie. Metoda, jaką przyjął, była pośrednia i zwodniczo prosta: można to próbować oszacować, sprawdzając, o ile wyższa musi być płaca w ryzykownych zawodach, jak na przykład praca strażaka, by znaleźli się chętni do jej podjęcia. (Jak natychmiast można zauważyć, jest ona mocno obciążona, choćby tak prozaicznymi czynnikami, jak ewentualność niedostępności innego sposobu zarobkowania. Przynajmniej w Polsce). Jako uzupełnienie badacz postanowił zadawać również bezpośrednie pytania dotyczące akceptowalnej rekompensaty za wzrost ryzyka śmierci. Ku swemu zdumieniu odkrył, iż na dwie kwestie, zasadniczo równoważne, jeśli chodzi o wymiar liczbowy, większość osób udziela odpowiedzi bardzo się różniących. Jesteśmy zazwyczaj relatywnie skąpi, gdy chodzi o redukowanie istniejącego ryzyka, w porównaniu z zachłannością wykazywaną w żądaniach sum za ryzyko dodatkowe. Wyglądało na to, że ryzyko nie ma po prostu swojej „obiektywnej” ceny. Potraktowawszy to jako nieco kłopotliwą ciekawostkę, Thaler chwilowo porzucił drążenie zagadnienia subiektywnych wycen własnego życia.

Z upływem lat zbierał jednakże coraz więcej takich okazów do swojej kolekcji dziwnych zachowań ludzi jako konsumentów, rzekomo, jak przyjęto wówczas wierzyć, racjonalnych i o spójnych preferencjach. Traf chciał, że przypadkowo spotkany na konferencji kolega $\mathrm{z}$ branży zwrócił jego uwagę na prace tandemu nieznanych mu dotychczas izraelskich psychologów.

Przeczytawszy wstępny szkic pracy dotyczący teorii niepewnych perspektyw, Thaler postanowił zrobić wszystko, by znaleźć okazję do 
współpracy z jej autorami - czy raczej, przynajmniej na początku, do nauki. Pociągając za wszelkie możliwe sznurki udało mu się uzyskać angaż na Uniwersytecie Stanforda w semestrze, w którym Daniel STATYSTYCZNY Kahneman i Amos Tversky gościnne prowadzili tam wykłady.

I tak to się zaczęło. Wieloletnia, trwająca do dziś dnia współpraca i przyjaźń pomiędzy Kahnemanem (oraz, do momentu jego śmierci, Tverskim) a młodszym Thalerem. Pierwszym namacalnym efektem tej znajomości była cytowana wcześniej praca Thalera z 1980 roku, „Ku pozytywnej teorii wyboru konmsumenckiego" (Toward a Positive Theory of Consumer Choice).

Choć po publikacji artykułu Daniel Kahneman poważnie obawiał się o możliwości otrzymania przez protegowanego stałego zatrudnienia na jakimkolwiek uniwersytecie, z perspektywy czasu początek lat osiemdziesiątych ubiegłego wieku wydaje się wręcz brzemienny w zmiany, które poskutkowały narodzinami nowego paradygmatu, jeśli można tym mianem określić zwrot większości ekonomistów od wyidealizowanych modeli matematycznych do ekonomii opartej na gruncie psychologii. W 1978 roku Nagrodę imienia Nobla w tej dziedzinie otrzymał bowiem Herbert Simon, twórca pojęcia ograniczonej racjonalności (bounded rationality). Maurice Allais już w 1953 roku opisał swój eponimiczny paradoks w pracy, która powoli przebijała się do świadomości (powoli, gdyż nie pomagał jej fakt, że pierwsza wersja opublikowana była w języku francuskim), a w 1988 roku został wyróżniony Nagrodą imienia Nobla.

Po odrzuceniu przez kilka wydziałów ekonomicznych Thaler otrzymał w końcu posadę na Uniwersytecie Cornell i mógł kontynuować badania, będąc jednym $\mathrm{z}$ kładących podwaliny pod dziedzinę, która jest obecnie niezwykle modna i nosi miano ekonomii behawioralnej. Nie musiał zbyt długo czekać na uznanie. Już po kilku latach został dostrzeżony, a kierownictwo jednego z wydawnictw Amerykańskiego Towarzystwa Ekonomicznego, Journal of Economic Perspectives, zwróciło się do Thalera z prośbą o prowadzenie regularnej kolumny opisującej odkrycia przeczące konwencjonalnemu postrzeganiu ludzi jako samolubnych, maksymalizujących swoją konsumencką użyteczność.

Jak to $\mathrm{w}$ rewolucjach bywa, sprawy nabierały przyspieszenia. W połowie lat dziewięćdziesiątych Thaler nie musiał już martwić się o perspektywy zatrudnienia, gdyż to o niego zabiegano. Jak na ironię, $\mathrm{z}$ ofertą współpracy wystąpił Uniwersytet w Chicago, cieszący się (nie)sławą, słuszną lub nie, najbardziej twardogłowych z piewców racjonalistów. Decyzja, jak by nie patrzeć, nader racjonalna, gdyż po 
dwóch dekadach inwestycja zwróciła się: dzięki niej uczelnia dopisała do swojej listy kolejnego ekonomicznego noblistę. Idee ideami, a zysk zyskiem, można by powiedzieć, gdyby władze uniwersytetu faktycznie kierowały się przeczuciem narastającej koniunktury egzotycznej dla nich gałęzi ich dyscypliny.

Omawiając wkład Thalera w ekonomię behawioralną, w pracy badacza można wyróżnić eksperymenty i analizy, które pomogły ugruntować w nauce trzy wielkie prawdy na temat Homo. Częściowo były one omawiane już powyżej. Osobom postronnym wydawać się mogą, co prawda, oczywiste i trywialne, ale czasem trywialnym oczywistościom najtrudniej uzyskać status nobliwej nauki, zwłaszcza w dziedzinie ekonomii.

Te trzy prawdy dotyczące ludzkości są następujące:

1. Nie zawsze chcemy postępować racjonalnie.

2. Nawet jeśli chcemy, częstokroć nasze rozumowanie zwodzi nas na manowce.

3. Nawet jeśli chcemy postępować racjonalnie i wiemy, jak to uczynić, częstokroć brak nam silnej woli.

\section{Maksymalizacja użyteczności a wartości etyczne}

Była mowa już o tym, że racjonalne kalkulacje częstokroć wcale nie są najbardziej racjonalną strategią postępowania. Ewolucja wyposażyła nas w efektywniejsze mechanizmy załatwiania spraw, bez angażowania zbytnich zasobów energetycznych i zbyt wielkiej ilości czasu.

Jednakże, poza częstym brakiem efektywności, racjonalność nie zawsze nawet jest tym, czego naprawdę chcemy. Częściowo jest to kwestia semantyczna i zależeć może od definicji słowa „racjonalność” oraz definicji użyteczności, której maksymalizowaniem zajmują się racjonalizatorzy. Załóżmy na chwilę, że rozsądek polega na osiąganiu jak największej użyteczności materialnej.

Jednym z dziwactw, jakie odnotował Thaler, badając homo nonoeconomicus, jest postawa omówiona w następującym przykładzie. Wyobraźcie sobie, że leżycie na plaży w ogromnie upalny dzień i marzycie o butelce schłodzonego piwa. Wasz kolega właśnie wybiera się na promenadę i proponuje zakup tego wymarzonego napoju, zapytując o maksymalną kwotę, którą jesteście skłonni zapłacić za tę przyjemność. Jaką sumę wymienicie, jeśli zakup ma się odbyć u sprzedawcy z przenośną chłodziarką, krążącego po deptaku, a jaką, jeśli jedynym dostępnym źródłem napitków jest restauracja pięciogwiazdkowego 
hotelu? Zakładamy, że marka i temperatura piwa w obu przypadkach będzie dokładnie taka sama. Jeśli nie robi wam różnicy miejsce robienia zakupów - gratulacje, właśnie wykazaliście się zdrowym ekonomicznym rozsądkiem. Jednakże większość osób w podobnej sytuacji odczuwa to inaczej: godzi się z faktem, że ceny w ekskluzywnym hotelu są, jakie są, choćby z powodu wysokich kosztów operacyjnych właścicieli takiego przybytku. $\mathrm{Z}$ drugiej strony, taka sama cena $\mathrm{u}$ obwoźnego sprzedawcy wyda się rozbojem w biały dzień, naruszeniem jakichś niepisanych reguł. Racjonalnie: albo przyjemność wypicia schłodzonego piwa marki $X$ jest warta 20 złotych, a wówczas nie ma znaczenia, gdzie dokonujemy zakupu, albo nie jest warta tej kwoty wówczas znowu nie ma znaczenia, gdzie byśmy je nabyli. A jednak sporo osób rozróżnia te sytuacje, czując, iż jest nie fair, jeśli takiej wysokiej ceny żąda właściciel wózka z generatorem.

Przytoczona sytuacja jest anegdotyczna i nie stanowi żadnego dowodu na to, że większość (i jaka większość?) osób wykazuje podobne reakcje. Prace Thalera dobitnie udokumentowały efekt postrzegania tego, co jest, a co nie jest fair, na wybory ludzi, którzy częstokroć gotowi są zrezygnować z części zysku w imię sprawiedliwości.

To zamiłowanie do sprawiedliwości można rozbić na trzy powiązane ze sobą elementy, które w dużej mierze można postrzegać jako kolejne stopnie.

Pierwszy szczebelek nieracjonalnej predylekcji do uczciwości: Ludzie często zachowują się (w swoim odczuciu) fair, nawet jeśli umniejsza to ich zyski, a jednocześnie ani nie ryzykują zemsty, ani nie liczą na wzajemność.

Niespodzianka? Miejmy nadzieję, że nie jest to aż tak zaskakujące. Jasne, prawo i (po części) religia mają stać na straży prawidłowego zachowania, pod groźbą kary ziemskiej lub pozaziemskiej. Chyba jednak chcielibyśmy wierzyć, że nasi bliscy i sąsiedzi nie powstrzymują się od masowych mordów i gwałtów tylko ze strachu przed spodziewaną karą. Odkrycie neuronów lustrzanych, tak skwapliwie podchwycone przez szeroką publiczność, stanowiło odpowiedź na to chyba jednak odwieczne marzenie, by homo homini nie okazał się jednak lupus.

Aby przetestować altruizm w warunkach laboratoryjnych, Daniel Kahneman, Jack Knetsch i Richard Thaler przeprowadzali grę nazwaną „Dyktator”, a wyniki przedstawili w artykule z 1986 roku [Kahneman, Knetsch, Thaler 1986a].

Każda gra przeprowadzana była $\mathrm{z}$ udziałem dwóch studentów, przy czym ani przed eksperymentem, ani po nim żaden $\mathrm{z}$ badanych nie 
miał pojęcia, kto był jego partnerem. Jednemu ze studentów wręczano 20 dolarów i stawiano przed wyborem: albo weźmie dla siebie 18 dolarów, a koledze odda 2 dolary, albo całą sumę podzieli po równo. I to koniec, nie było kolejnej rundy, w której gracze zamienialiby się rolami, ani nie mieli żadnej szansy nawzajem poznać swoich tożsamości.

Oczywiście, 18 dolarów to o 8 dolarów więcej niż 10 dolarów, które dyspozytor pieniędzy otrzymałby przy równym podziale. Dlaczego zatem ktokolwiek miałby rezygnować z ośmiu dolarów, skoro nie mógł za to uzyskać nawet wdzięczności (anonimowość!)? A jednak $76 \%$ studentów dzieliło pieniądze po równo.

Grę „Dyktator” powtórzyło wielu różnych badaczy, przeważnie w wersji, w której dyspozytor pieniędzy nie miał tylko dwóch opcji do wyboru, ale mógł całkowicie samodzielnie zdecydować o proporcji podziału. Z metaanalizy tych wszystkich badań wynika [Engel 2011], iż tylko $36 \%$ badanych zabrało dla siebie maksymalną możliwą kwotę (odsetek ten był jednakże wyraźnie wyższy wśród studentów ekonomii). Średnio badani oddawali niemal jedną trzecią sumy, a 17\% wybierało podział równy.

Kolejnym szczeblem na drabinie nieracjonalnego umiłowania sprawiedliwości jest rezygnacja z części zysku w celu ukarania osoby, której zachowanie postrzegane jest jako nieuczciwe. Ten efekt jest zwykle opisywany w odniesieniu do innej gry laboratoryjnej, nazywanej „Ultimatum”, i został opisany już przed Thalerem [Güth i in. 1982]. Podobnie jak w „Dyktatorze”, w każdej rozgrywce biorą udział dwie osoby (w praktyce są to zazwyczaj studenci), które się nie znają (nie znały się przed eksperymentem i nie poznały się po nim). Jedna $\mathrm{z}$ nich dostaje pewną sumę pieniędzy do podziału między siebie a partnera, i może tego dokonać w dowolny sposób. W odróżnieniu jednakże od „Dyktatora” strona druga nie jest tu bierna. Jej rolą jest zaakceptowanie oferty - wówczas każdy zatrzymuje taką kwotę, jaką zaproponował dzielący, bądź odrzucenie - wtedy obaj zostają z pustymi rękoma. Nie ma drugiej rundy, nie ma negocjacji. Propozycja tak lub nie - finał.

Gdybyście byli dzielącymi, jaki procent zaproponowalibyście partnerowi? Gdybyście byli biorcami, zaakceptowalibyście dowolnie małą sumę?

$\mathrm{Z}$ racjonalnego punktu widzenia podział, w którym nie dostajecie nic, możecie odrzucić z czystej złośliwości, nic przy tym nie tracąc. Ale choćby jeden dolar to więcej niż nic, więc nawet skrajnie nierów- 
na propozycja - byle niezerowa - powinna być racjonalnie zaakceptowana. Biorąc pod uwagę rozumowanie drugiej strony, można myśleć, że osoba dzieląca powinna zaproponować cokolwiek - by unikSTATYSTYCZNY nąć złośliwości - ale jak najmniej, by jak najmniej uszczknąć samej sobie.

A jak to wygląda w praktyce? Dysponenci pieniędzy są przeważnie nieracjonalnie hojni, a decydenci - nieracjonalnie mściwi, odrzucając niezerowe udziały, postrzegane jednakowoż jako niewystarczające i niesprawiedliwe.

Nadspodziewana szczodrość pierwszych z graczy ilustruje omawiany już poprzednio efekt. Ludzie zachowują się często w sposób uważany przez siebie samych za uczciwy, nawet kosztem korzyści materialnej. Mściwość strony drugiej ilustruje dążenie do karania osób zachowujących się nie fair, ponownie nawet kosztem własnym. Gra „Ultimatum” jest chyba najsłynniejszą i najczęściej przeprowadzaną z gier z zasobnika ekonomii eksperymentalnej, a zbliżone rezultaty otrzymuje się przy różnych kwotach do rozdysponowania (nawet znacznych) i w różnych kulturach.

Trzecim szczeblem nieracjonalnego altruizmu jest karanie osób, które zachowały się nie w porządku, ale wobec kogoś innego niż my sami. I to karanie kosztem własnym. Aby zaprezentować ten efekt, Kahneman, Knetsch i Thaler [1986b] dodali drugi etap do gry „Dyktator" (w wersji, w której na etapie pierwszym możliwy był podział 10-10 lub 18-2). Badani (niebiorący udziału w etapie pierwszym) mieli do wyboru dwie opcje. W pierwszej brali dla siebie 5 dolarów, a drugie 5 przekazywali osobie, która w pierwszym etapie zdecydowała się na równy podział. Opcja druga była taka, że badany dostawał 6 dolarów, a kolejne 6 przekazywał osobie, która na etapie pierwszym wykazała się zachłannością, zatrzymując dla siebie większość sumy. Niemal $3 / 4$ badanych decydowało się na opcję pierwszą. Wybierali zatem nagrodzenie osoby bardziej na to zasługującej, nawet kosztem własnym (utraty jednego dolara).

Taką dążność do ,altruistycznego karania” (nawet jeśli w pierwszym momencie to sformułowanie wydać się może oksymoronem) zaobserwowano i w innych kontekstach, między innymi w grach symulujących użytkowanie dóbr wspólnych (common-pool resources) prowadzonych przez Elinor Ostrom (zmarłą w 2012 laureatkę Nagrody imienia Nobla w dziedzinie ekonomii za rok 2009) i jej współpracowników.

Czasem próbuje się obejść tę rezygnację z maksymalizacji użyteczności. Przedefiniowuje się po prostu użyteczność tak, by obejmo- 
wała nie tylko bezpośrednie korzyści materialne, ale i użyteczność płynącą na przykład z satysfakcji z dawania wyrazu moralnemu oburzeniu. Przypomina to jednakże obronę egoizmu. Każdy przykład zachowania altruistycznego można skontrować, sugerując egoistyczną korzyść choćby z dobrego samopoczucia (jeśli już nie samolubność genów). Koniec końców, przy odpowiednich definicjach łatwo wyeliminować i altruizm, i irracjonalność.

Można jednakowoż przyznać, co większości ludzi (choć niekoniecznie ekonomistów) uczyni zapewne bez zbytnich oporów, a może i z dumą, iż, faktycznie, bycie człowiekiem to nie tylko maksymalizowanie użyteczności. Tak właściwie można było to powiedzieć i bez specjalnych eksperymentów.

\section{(Nie)racjonalność}

No dobrze, ludzkie wartości wykraczają daleko poza płytkie materialne interesy. Nie da się jednak zaprzeczyć, że stan posiadania jest dla większości z nas ważnym czynnikiem istnienia. Czasem zatem usiłujemy racjonalnie zarządzać własnymi finansami. Pięknie by było, gdybyśmy bez trudu planowali wydatki tak, jak to zakładali neoklasyczni ekonomiści, czyli gdybyśmy „wygładzali” konsumpcję w ciągu całego życia: oszczędzali na gorsze czasy w latach thustych, by czerpać z tych zapasów w latach chudych. Osiągnięcie tego wymagałoby od nas nie tylko sporych możliwości intelektualnych i niemal proroczych zdolności przewidywania (przyszłych wydarzeń, sytuacji na rynku i tak dalej), ale i ogromnej samodyscypliny. Ale daleko nam do takich herosów, to raczej pewne. Richard Thaler skupił się na wykazaniu pewnych szczególnych efektów uwłaczających naszej racjonalności.

Pierwszym z nich jest efekt posiadania (endowment effect), ściśle powiązany z awersją do straty. Ile bylibyście gotowi zapłacić, by uzyskać dobro $\mathrm{X}$ ? Ta suma to miara tak zwanego willingness to pay, WTP (skłonności do zapłacenia). Wyobraźcie sobie, że jesteście w posiadaniu dobra X. Za jaką kwotę bylibyście skłonni je odstąpić? Ta wielkość jest miarą tak zwanego willingness to accept, WTA (skłonności do zaakceptowania). Efekt posiadania przejawia się w tym, iż zazwyczaj WTA jest większe niż WTP. W miejsce dobra X można podstawić różne rzeczy. Choćby ułamek waszego życia, jak w przykładzie z ryzykiem śmierci przytaczanym wcześniej. W laboratorium, rzecz jasna, nie wolno było szafować życiem, zatem gra szła o znacznie mniejszą stawkę - o kubki z logo uniwersytetu. 
W eksperymencie przeprowadzonym przez Kahnemana, Knetscha i Thalera [1990] studenci stawali wobec możliwości zakupu bądź sprzedaży kubka z logo uniwersytetu, przy czym połowa z nich kubek STATYSTYCZNY otrzymywała i mogła go odsprzedać, a druga połowa badanych otrzymywała pewną kwotę i mogła część z niej przeznaczyć na odkupienie kubka od kolegów. Okazało się, że osoby będące w posiadaniu kubka wyceniały go znacznie wyżej niż osoby, które go nie otrzymały na początku eksperymentu (co przejawiało się w mniejszej niż przewidywana liczbie transakcji sprzedaży-kupna). Najwyraźniej sam fakt bycia posiadaczem przedmiotu uczynił go w oczach właściciela bardziej cennym.

Nawet jeśli doświadczenie z kubkami rozciągnąć można na szerszą kategorię sytuacji, niechęć do rozstawania się z posiadanymi dobrami wydaje się, mimo wszystko, potencjalnie mniej kosztowna niż kolejne badane przez Thalera efekty.

Pierwszy z nich to tzw. krótkowzroczność (myopia), czyli koncentrowanie się na zbyt krótkiej perspektywie czasowej. Jeżdżąc taksówkami, Thaler zainteresował się tym, w którym momencie kierowcy, którzy wynajmują pojazdy na dwanaście godzin, płacąc ryczałtem, decydują się na zakończenie dnia pracy. Dwunastu godzin bowiem zazwyczaj nie wyjeżdżają, byłoby to zbyt wyczerpujące. Okazało się, iż większość z nich działa wedle prostego algorytmu. Zakłada pewną sumę, którą musi zarobić każdego dnia, a po jej uzyskaniu kończy pracę. Pozornie wydaje się to całkiem sensowne. Po bliższym przyjrzeniu się wychodzą jednak na wierzch ukryte mankamenty takiego rozwiązania. Otóż w dni, w których jest spore zapotrzebowanie na taksówki - na przykład przy brzydkiej pogodzie - w ciągu jednej godziny kierowca zarabia więcej niż w dni o słabym zapotrzebowaniu na ich usługi. Ale to oznacza jednocześnie, że taksówkarz wcześniej osiąga założony cel i zaprzestaje pracy, czyli rezygnuje z godzin najbardziej opłacalnych. Gdyby planował bardziej długofalowo, celując w określony zarobek miesięczny zamiast dziennego, uzyskałby go, przepracowując mniejszą liczbę godzin (lub zarobił więcej przy tej samej liczbie godzin).

Podobnie niekorzystna jest zbyt skrócona perspektywa przy podejmowaniu decyzji inwestycyjnych. Te bardziej opłacalne (i zarazem bardziej ryzykowne) wykazują większe wahania. Obserwowanie codziennych kursów (czy innych wskaźników finansowych) napawa większym strachem i sugeruje większą ostrożność niż te same dane po uśrednieniu na dłuższym przedziale czasowym. 
Kolejny z efektów opisywanych przez Thalera, czyli dziwactwa tzw. umysłowej rachunkowości (mental accounting), sytuuje się na granicy pomiędzy błędami poznawczymi a problemami z samokontrolą, które stanowią trzecią przeszkodę na drodze wiodącej do zachowań racjonalnym (przypomnijmy: pierwsza - wcale nie chcemy być racjonalni; druga - nie wiemy, jak; trzecia - nie wystarcz nam do tego siły woli). Rzecz w tym, że niektóre osoby stosują taką ekwilibrystykę rachunkową, właściwie nie wiedząc, że istnieje lepsze (w sensie większej opłacalności) rozwiązanie. Inni natomiast zupełnie świadomie starają się rzucać kłody pod nogi tym mieszkającym w większości ludzi „obcym”, sięgającym w chwilach nieuwagi rozważnego „ego” po kartę kredytową, kolejne ciastko czy przestawiającym budzik pół godziny do przodu.

A jak to wygląda?

W Polsce karty kredytowe nie są może jeszcze jakoś specjalnie rozpowszechnione, trudno zatem stwierdzić, na ile Polacy wykazują się specyfiką zaobserwowaną przez Thalera wśród własnych rodaków. W każdym razie w Stanach Zjednoczonych nie jest niczym dziwnym, że ta sama osoba ma obciążoną kartę kredytową (którą spłaca ze sporym procentem), a jednocześnie pewną sumkę odłożoną na koncie oszczędnościowym, oprocentowanym skromniutko bądź wcale. Oczywiście to się nie kalkuluje. Bilans byłby korzystniejszy, gdyby wyjąć oszczędności, uregulować rachunek z karty, a następnie każdego miesiąca kwotę, która zostałaby przeznaczona na spłatę odsetek, wkładać na konto oszczędnościowe. Proste? Niezupełnie. Dla wielu osób gotówka na bieżącym koncie byłaby zbyt wielką pokusą, by powstrzymać się od wydania jej, zamiast odłożenia na konto oszczędnościowe. Przez jakiś czas ktoś taki cieszyłby się wyższą stopa życiową (brak konieczności spłaty odsetek). Najprawdopodobniej wkrótce uległby jakiejś większej pokusie (w końcu już raz się to zdarzyło) i znowu użyłby karty kredytowej. Koniec końców, ponownie miałby odsetki do spłaty. Czyli wróciłby do sytuacji wyjściowej - poza faktem, że już nie miałby sumy odłożonej na koncie oszczędnościowym.

Jeśli świadomie godzimy się na to, by płacić określoną kwotę za trzymanie w ryzach naszego alter ego, to pół biedy - niektórzy płacą osobistym coachom, by pilnowali ich diety czy ćwiczeń. Czy finansów. Kto osądzi, co jest dziwniejsze: wydawanie pieniędzy na to, by pieniędzy nie wydawać, czy wydawanie pieniędzy na przyglądanie się przez półtorej godziny dwudziestu trzem facetom biegającym po murawie, przy czym jeden $\mathrm{z}$ nich bywa w śmiesznym pasiaku albo czarnym wdzianku? 
Gorzej, jeśli odbywa się to niezupełnie świadomie i potencjalnie powoduje znaczne straty. Jeśli firma nie potrafi elastycznie przetransferować funduszy z jednej przegródki do innej, może stracić wspaniałą okazję do interesu albo nawet upaść. A nawet, jeśli nie tracimy wiele, warto uświadamiać sobie wszystkie możliwe opcje i świadomie spośród nich wybierać.

No właśnie, jak to jest z tymi wyborami? Jeśli już wybierać (choć wybierać, jak wspominano wcześniej, nie zawsze pragniemy), to chcielibyśmy tego dokonywać i świadomie, i w sposób wolny, a także, oczywiście, skutecznie, by nasze wybory nie pozostawały na papierze. Rzecz jasna, na drodze do ich realizacji stanąć mogą czynniki obiektywne, zewnętrzne. Nader często jednakże okazuje sie, iż to my sami jesteśmy dla siebie najpoważniejszą przeszkodą.

\section{Słabość silnej woli}

Jak to jest $\mathrm{z}$ tą silną wolą - każdy chyba wie. Dwadzieścia kolejnych roczników kalendarzy z tym samym postanowieniem noworocznym („odstawić czekoladę") mówi same za siebie.

Kto nigdy nie zjadł jednego ciastka za dużo, nie wypił jednego kieliszka ponad miarę, nie kupił czegoś, na co go właściwie nie było stać - zdając sobie sprawę, że już za moment będzie cierpiał katusze z powodu poczucia winy? Dlaczego nie możemy ustalić planu optymalnego postępowania, a następnie po prostu się go trzymać?

No cóż, pewnie dlatego, że jesteśmy ludźmi.

Zasadniczo nie jest to, bycie człowiekiem, takie znowu złe, choć pewne aspekty naszego funkcjonowania można by ulepszyć. Na podstawie sławnych testów Marshmellow Walter Mishel udowadniał, iż osoby o wyższym stopniu samokontroli osiągają w życiu większy sukces - i że stopień ten jest lepszym predyktorem sukcesu niż na przykład inteligencja czy zdolności [Mishel 2014]. Szczęśliwie Ray Baumeister argumentuje, iż silna wola jest jak mięsień - męczy się w czasie używania, ale i można ją trenować [Baumeister, Tierney 2011]. Można też, jak zauważyli H.M. Shefrin i Richard Thaler, używać różnych sztuczek. Uderzyło ich, iż wiele osób trzyma pieniądze na specjalnym (nieoprocentowanym) koncie świątecznym, z którego wypłacić je mogą tylko raz w roku, 1 grudnia. Zasadniczo nie jest to opłacalne, tak samo, jak nieopłacalne jest spłacanie karty kredytowej, mając oszczędności na innym koncie. Jeśli jednakże potraktujemy jednostkę jako zespół dwóch $\mathrm{w}$ istocie osób, zacznie się to jawić jako 
rozsądna forma zabezpieczenia przed konfliktem. Różnie można nazwać te dwie jaźnie, zamieszkujące jedno ciało. Id i ego, ja-racjonalne i ja-impulsywne, ja-chwilowe i ja-długofalowe czy inne dychotomie, choćby tak obrazowe, jak starożytny woźnica i narowisty rumak. Faktem jest, że impulsywnie dążymy do zaspokojenia chwilowej zachcianki, natomiast rozsądek podpowiada nam, że czasem (lub często) nie jest to najkorzystniejsze w perspektywie długofalowej. Ale czy naprawdę obchodzi nas, co będzie za dziesięć lat? A za rok? Za miesiąc? Za pół godziny?

Im krótsza perspektywa, tym bliższa staje nam się ta osoba z przeszłości. Zasadniczo raczej utożsamiamy się z samymi sobą za piętnaście minut. Spróbujcie zrelaksować się przed bolesnym zabiegiem, mówiąc sobie, że tak naprawdę was to nie dotyczy, tylko jakiejś innej osoby, różnej od was o cały kwadrans. Nie działa? Zatem raczej odczuwacie tożsamość. A spróbujcie odczuć to samo przerażenie na myśl o zabiegu, któremu zostaniecie poddani za lat dwadzieścia kilka. Wzruszacie tylko ramionami? Gdyby tak łatwo było wzbudzić w nas zainteresowanie własnym odległym wcieleniem, wszyscy dawno już pozbyliby się szkodliwych nałogów, uprawiali jogę i jedli kiełki. To zdystansowanie od przyszłego ,ja” potwierdza neurofizjologia. Gdy badanym w skanerze MRI polecono myśleć o samych sobie, aktywna była pewna część mózgu, powiedzmy, I, gdy zaś myśleli o innych osobach - część mózgu, którą określmy jako A. (Ale przy myślach o mamusi bardziej pracowała część I!). A gdy mieli myśleć o samych sobie w dalszej przyszłości? Owszem, część A! My sami z przyszłości to osoby jakby obce, przynajmniej taka jest nasza reakcja emocjonalna. Po co zatem się dla nich poświęcać?

Na podstawie ankiet Thaler udokumentował zjawisko tak zwanego hiperbolicznego dyskontowania. Nie jest bez sensu to, że wolimy dostać sto złotych teraz niż za rok. Nawet nie biorąc pod uwagę inflacji, cokolwiek kupimy sobie za te sto złotych, mamy możliwość cieszenia się tym o rok dłużej. Albo możemy zdecydować zachować tę sumę na później, wkładając ją na wysoko oprocentowane konto. Jeśli zatem wolimy dostać sto złotych teraz niż, powiedzmy, 200 złotych za rok, nie ma w tym nic nieracjonalnego. Nie musi być nawet nieracjonalne, jeśli wolimy sto złotych teraz niż pięć tysięcy za rok. Jeśli na przykład jestem znakomitym inwestorem i potrafię przez rok uzyskać dziesięć tysięcy procent zysku - za rok będę w posiadaniu dziesięciu milionów, zatem wcale nie opłacałoby mi się czekać na te nędzne pięć tysięcy. Jeśli wolę $x$ złotych teraz niż $2 x$ złotych za rok - to jest to dys- 
kontowanie. Ale jeśli wolę $x$ złotych teraz niż $2 x$ złotych za rok, ale mając wybór pomiędzy $2 x$ za dziesięć lat albo $x$ za dziewięć wybieram czekanie na $2 x$ - to nie jest już uważane za racjonalne i nazywane STATYSTYCZNY właśnie dyskontowanie hiperbolicznym. Jeśli bowiem drugie $x$ nie jest warte czekania przez rok teraz, dlaczego miałoby być warte za dziewięć lat? (Pomijamy tu sytuacje tego typu, że mam akurat cynk i chcę natychmiast kupić bitcoiny, dlatego teraz czekać nie mogę, a za dziewięć lat będę mogła; odnosimy się do okoliczności typowych). Zjawisko hiperbolicznego dyskontowania jest kolejną ilustracją tego, że zupełnie inaczej traktujemy ,ja" teraźniejsze (my prawdziwi) i ,ja" przyszłe (ktoś niemal obcy). Zasadniczo jednakże jest to reakcja głównie emocjonalna. Mało kto zupełnie świadomie uzna, że ma w nosie to, czy za dziesięć lat umrze z głodu. Raczej nie wystarcza nam empatii wobec tego odleglejszego ,ja”. Częstokroć próbujemy zatem samych siebie przechytrzyć.

Shefrin i Thaler opracowali model ,ja planującego" i ,ja działającego" (planer-doer model) [Thaler, Shefrin 1981]. „Ja planujące” powiązane jest z czynnością kory przedczołowej i stara się maksymalizować długofalową użyteczność w ciągu całego życia jednostki. ,Ja działające" natomiast zakorzenione jest w impulsywnym układzie limbicznym, nie lubi odraczania gratyfikacji i w ogóle zachowuje się jak rozpuszczony bachor. Nasze decyzje podejmowane są w ciągłym napięciu pomiędzy tymi dwoma „podmiotami”, z których każdy dąży do osiągnięcia swoich własnych celów, długofalowych lub krótkofalowych.

\section{Impuls}

Skoro czyha na nas tyle przeszkód, o które możemy potknąć się na drodze do efektywnego ,zarządzania” własnymi finansami i życiem w ogóle, Thaler proponuje, by odgórnie nieco nakierowywać nasze wybory. Nazywa to „szturchnięciem”, „popchnięciem” (we właściwym kierunku), czyli po angielsku nudge. Taki tytuł nosi jego bestsellerowa książka, napisana w 1999 roku we współpracy z Cassem R. Sunsteinem, przetłumaczona na język polski jako „Impuls” [Thaler, Sunstein 1999].

Najbardziej zapewne znany przykład, ilustrujący, jak miałoby to działać, dotyczy transplantacji narządów. Wiadomo, jak wiele osób zawdzięcza życie przeszczepom, i że dostępnych organów jest stanowczo zbyt mało, by pomóc wszystkim, których mogłyby one ura- 
tować. $\mathrm{Z}$ tego punktu widzenia istotne jest, by jak najwięcej osób było potencjalnymi dawcami. Tymczasem w różnych krajach ich odsetek różni się diametralnie. Przykładowo w Austrii jest to 99\%, a w Niemczech $-12 \%$. Co różni te kraje, tak przecież podobne kulturowo? Otóż w Austrii (podobnie jak w Polsce) obowiązuje domniemana zgoda, choć, oczywiście, każdy może zadeklarować niezgodę. Tymczasem w Niemczech zakłada się, iż obywatel, który nie wyraził zgody explicite, zgody tej nie wyraża. Jak widać, większość osób pozostaje przy opcji „domyślnej”. Część z pewnością z powodu zwykłej niewiedzy i niezainteresowania tematem. Być może po przeczytaniu tego akapitu któryś z czytelników, uświadomiony w kwestii swojej domniemanej zgody na pobranie narządów, czym prędzej uda się zastrzec swoją pośmiertną integralność. Można by się jednak założyć, że większość z tych, którzy do tej pory nie poświęcali zbyt wiele czasu rozważaniom na ten temat, uzna - a, niech tak będzie. Prawdopodobnie byłoby tak również, gdyby wyczytali, że w naszym kraju domyślna jest niezgoda na pobranie narządów. W końcu brak decyzji jest tylko brakiem działania. Podjęcie decyzji wymagałoby jakichś uzasadnień, namysłu, i - co może nie najmniej istotne, czasu poświęconego na podjęcie konkretnych kroków.

W innych sprawach również mamy skłonność do akceptowania status quo. Po części z lenistwa, po części dlatego, że jest to sugestia co do „normy”, a cokolwiek chcielibyśmy myśleć o samych sobie, większość z nas jest instynktownymi konformistami. Poza wszystkim dążność do pozostania przy istniejącym stanie rzeczy, o ile nie jest on $\mathrm{z}$ jakiegoś powodu nie do zniesienia, uwalnia nas od miliona drobnych decyzji, z których każda może mieć miliony potencjalnych opcji. Jak wskazywaliśmy, tego typu „świadome” życie stałoby się koszmarem.

$\mathrm{Z}$ tej przyczyny osoby niezbyt dobrze znające się na oprogramowaniu i bez specjalnych preferencji, instalując nową aplikację, akceptują wersję standardową. Zanim Google uczynił eksperta z każdego nas, większość osób akceptowała zalecaną przez lekarza terapię, nie dopytując, czy nie lepiej byłoby przyjmować dwa razy większe dawki bądź w ogóle zamienić lek. Wielu z nas kupuje tę samą markę pasy do zębów od lat, mimo że w międzyczasie pojawiły się dziesiątki nowych i być może teraz wybralibyśmy coś innego. Kolokwialnie mówiąc, zazwyczaj nie chce się nam deliberować zbyt długo nad poszczególnymi sprawami i, częstokroć, jest to postawa jak najbardziej rozsądna, oszczędzająca czas i energię psychiczną. Gorzej, jeśli to specyficzne lenistwo waży na bardziej znaczących decyzjach. Jeśli trzymamy pie- 
niądze na niskooprocentowanym koncie, bo nic nas nie motywuje, by przejrzeć inne dostępne opcje i założyć korzystniejszą lokatę. Jeśli nie korzystamy z bezpłatnych badań profilaktycznych, choć zajmują pół STATYSTYCZNY godziny $\mathrm{w}$ roku, a mogą uratować życie. Jeśli bezmyślnie klikamy „akceptuj”, a wirus komputerowy niszczy zawartość naszego komputera i efekty wielomiesięcznej pracy.

Nie z każdej sytuacji istnieje proste wyjście. W wielu jednakże, odpowiednio konstruując opcje domyślne, odgórnie można nieco pomóc $\mathrm{w}$ dokonywaniu właściwych wyborów.

Jeśli „dokonywanie wyboru pod wpływem manipulacji” brzmi jak oksymoron, tak samo wewnętrznie sprzeczne wydać się może określenie ,patriarchalny libertarianizm”, ukute i promowane przez Thalera. Na czym miałby on polegać?

Weźmy przykład profilaktyki. Wczesne wykrywanie nowotworów byłoby korzystne zarówno dla jednostki (większe szanse wyzdrowienia), jak i społeczeństwa (mniejsze koszty leczenia) oraz pracodawców (mniejsze koszty absencji pracowniczej). Przymusowe badania zostałyby natychmiast oprotestowane jako gwałcenie wolności, zatem nie tędy droga. Ale gdyby tak każda kobieta dostawała corocznie skierowanie z zakładu pracy na cytologię, a każdy mężczyzna w odpowiednim wieku termin badania prostaty $\mathrm{w}$ pobliskiej przychodni i $\mathrm{w}$ godzinach pracy? Oczywiście, udział w badaniu byłby dobrowolny. Każdy pracownik mógłby wypełnić oświadczenie, iż nie chce być częścią programu profilaktycznego. Jaki procent osób zdecydowałoby się na odmowę badań? Sądząc przez analogię do obserwowanych już zjawisk, niewielki. Czy byłoby to korzystne? Owszem, dla wszystkich zainteresowanych stron. Z poszanowaniem wolności jednostki.

Czy to poszanowanie nie byłoby jednakże tylko formalne? Czy w warunkach celowej manipulacji można mówić o poszanowaniu autonomii? Z innej strony patrząc, jakieśs ustawienia domyślne zawsze muszą istnieć. Czy mając wiedzę o ich istotnym wpływie na ludzkie wybory, nie utraciliśmy już jakiejś „niewinności” w tym względzie? Jakiekolwiek warunki wstępne zostaną ustalone, wybierający je nie mogą dokonać tego w próżni poznawczej, ale raczej ze świadomością tego, że każda opcja będzie w jakiś sposób kształtować ludzką percepcję. Wybór nie polegałby zatem na tym, czy wpływać na wybory, czy nie, bo to w świetle najnowszych badań nieuniknione, tylko - jak wpływać.

Kwestie tego typu, jak wszystkie zagadnienia światopoglądowe, raczej nie znajdują łatwych rozwiązań i odpowiedzi. Czy raczej od- 
powiedzi, co do których panowałaby zgoda. W każdym razie Richard Thaler silnie opowiada się za rozwiązaniami typu ,impuls”.

Takie zachęty $\mathrm{w}$ postaci domyślnych opcji miałyby doskonale działać w przypadku dobrowolnego przystępowania do planów emerytalnych, ubezpieczeń zdrowotnych czy programów oszczędnościowych, do których wszyscy byliby zapisywani domyślnie, a dobrowolność polegałaby na możliwości wypisania się. Odgórna troska z zachowaniem poszanowania wolności jednostki mogłaby, wedle autorów „Impulsu”, przyjmować również postać szczególnych regulacji, delikatnie popychających w „dobrym” kierunku. Zamiast obowiązku noszenia kasku w trakcie jazdy motocyklem (pogwałcenie wolności, przeciwne libertarianizmowi) osoby pragnące poczuć wiatr we włosach musiałyby uzyskiwać specjalne prawo jazdy i przechodzić dodatkowy kurs (drobna przeszkoda, przejaw troskliwego paternalizmu). Choć, być może, w tym akurat przypadku wystarczyłoby obowiązkowe podpisywanie oświadczenia woli: „Tak, jestem cholernym idiotą i pragnę umrzeć przedwcześnie". Czasem regulacje miałyby dotyczyć osoby nie korzystającego, ale dostarczającego pewne usługi. Tutaj postulaty Thalera i Sunsteina brzmią jak petycje Rzecznika Ochrony Praw Konsumenta: wyraźniejsze wyspecyfikowanie warunków umowy, w szczególności tych niekorzystnych; a te niekorzystne przedstawione w taki sposób, który byłby dla klienta bardziej obrazowy. Nie tak dawno temu na ulicach polskich miast pojawiały się osoby z Greenpeace'u, namawiające do wypełnienia zobowiązania do regularnych przelewów na rzecz rysi, łosi czy łososi. „Tylko złotówka dziennie”, brzmiały zachęty. Oczywiście, jest to równoznaczne z, „tylko 365 złotych rocznie". Tylko? W takiej formie kwota wydaje się już większa. Regulacje proponowane w „Impulsie” miałby ukrócić tego typu manipulacje, przeprowadzane na odczuciach odnośnie do wielkości liczb.

Opcje domyślne i specjalne regulacje prawne wydają się dość odlegle. Łączy je jednakże świadomość tego, w jaki sposób nasza ludzka konstytucja - właściwie homo sapiens, w odróżnieniu od homo oeconomicus - wiedzie nas na manowce i ku własnej zgubie. Propozycje libertariańskiego paternalizmu mają nam pozwolić być ludźmi, ale wyniki mieć nieco bliższe temu, jakie mieliby „ekoni”.

\section{Nagroda}

Komitet Noblowski nie słynie z tego, by skłonny był wybiegać przed szereg, iść w awangardzie, przecierać nowe szlaki. Nagroda przyznana 
naukowcowi reprezentującemu nurt behawioralny w ekonomii najlepiej świadczy o jego przynajmniej dość szerokiej akceptacji w kręgach akademickich. Choć po ogłoszeniu zwycięzcy pojawiały się $\mathrm{w}$ prasie artykuły nazywające decyzję „,kontrowersyjną”, trudno byłoby bronić takie stanowisko ze względu na dyscyplinę, która już wcześniej kilkakrotnie została $\mathrm{w}$ ten sam sposób uhonorowana. Właściwie, bardziej kontrowersyjny niż dotyczący dziedziny mógłby być wybór jej reprezentanta. Choć Richard Thaler był w pewnym momencie członkiem mniejszości, trudno powiedzieć, by samodzielnie podważał skostniały paradygmat. W każdym momencie miał grono współpracowników - niektórzy z nich byli nawet raczej mentorami lub inspiracją. Ledwie kilka $\mathrm{z}$ prac Thalera, wymienionych $\mathrm{w}$ podsumowaniu jego dokonań zamieszczonym na stronie www.noberprize.org, napisanych jest samodzielnie. Znakomita większość badań odbywała się we współpracy, częstokroć, jak przyznaje $\mathrm{w}$ różnych momentach sam Thaler na stronach naukowej autobiografii „Misbehaving” [Thaler 2015], inspirowanej przez drugą stronę.

Nie ma chyba jednakże złudzeń co do tego, że nagradzani są zawsze ci najbardziej zasłużeni, najbardziej błyskotliwi, z największymi dokonaniami. Widzialność i słyszalność liczą się równie bardzo - albo i bardziej. W końcu ktoś musi nominować daną osobę, by Komitet Noblowski miał szansę w ogóle rozpatrywać jej kandydaturę. Samotny geniusz, nie zabiegający o zaszczyty, ma na starcie gorsze widoki.

Richard Thaler do cichych i skromnych nie należy. Doskonale potrafi odnaleźć się zarówno w świecie nauki, jak i polityki czy nawet autoreklamy. Był nieformalnym doradcą prezydenta Baracka Obamy, zarówno w czasie prezydentury, jak i reelekcyjnej kampanii w 2012 roku. Już całkiem formalnie piastował stanowisko konsultanta w administracji premiera Wielkiej Brytanii Davida Camerona. Od 1991 roku jest jednym z dyrektorów Projektu Ekonomii Behawioralnej Narodowego Biura Badań Ekonomicznych (National Bureau of Economic Research Behavioral Economics Project), największej ekonomicznej organizacji badawczej w Stanach Zjednoczonych. Jest jednym z założycieli firmy zarządzającej aktywami „Fuller \& Thaler Asset Management" przynoszącej spektakularne zyski. Jest doradcą Allianz Global Investors. Wygłasza dziesiątki płatnych wykładów (,zbyt wiele, by spamiętać”, jak sam napisał w swoim oświadczeniu o potencjalnych konfliktach interesów zamieszczonym na osobistej stronie internetowej [Thaler 2013]). Jest też autorem dwóch bestsellerów. Wystąpił nawet epizodycznie u boku Seleny Gomez w filmie „The Big Short” z 2015 roku opowiadającym o kryzysie z roku 2008. 
W wywiadzie przeprowadzonym w 2012 roku Gregory Karp, reporter „Chicago Tribune”, zadał Thalerowi pytanie o widoki na otrzymanie Nagrody imienia Nobla [Karp 2012]. „Mój przyjaciel, Daniel Kahneman, zaprosił mnie w 2002 roku w charakterze towarzysza przy odbiorze jego nagrody. Przekonałem się wówczas, że Szwedzi potrafią robić świetne przyjęcia. Zatem, jeśli zadzwonią, na pewno nie odmówię", odparł skromnie Thaler.

Zadzwonili. Oficjalne uzasadnienie Komitetu Noblowskiego brzmi: „Za wkład w ekonomię behawioralną" [Nobel Media 2014b]. A bardziej szczegółowo: „Badając konsekwencje ograniczonej racjonalności, preferencji społecznych i braku samokontroli (Thaler) wykazuje, jak te cechy ludzkie systematycznie wpływają na indywidualne decyzje, a także wyniki rynkowe". To się zgadza. Tyle, że to nie on pierwszy i nie jedyny.

Z drugiej strony, wiele nagród przyznano osobom, co do których można mieć sporo większe wątpliwości odnośnie do ich zasług. Niemal 400 tysięcy osób podpisało w ubiegłym roku petycję w sprawie odebrania nagrody pokojowej przyznanej w 1991 roku Aung San Suu Kyi, za milcząca zgodę na prześladowania Rohindżów w kraju (Mjanma, dawniej Birma), w którym sprawuje stanowisko szefowej rządu...

\section{Ekonomia behawioralna w rozkwicie?}

Prawdopodobnie większość z nas zgodziłaby się ze stwierdzeniem, że homo na ogół nie jest oeconomicus, i w tym przyznałaby rację ekonomii behawioralnej.

Prawdopodobnie Nagroda imienia Nobla dla Thalera jest też wyrazem uznania ze strony establishmentu dla tej dziedziny.

Czy między tymi dwiema konstatacjami - że człowiek nie jest racjonalny i że ekonomia behawioralna jest szacowną dziedziną wiedzy - zachodzi związek konieczny?

Nie negując bynajmniej nieracjonalności, można postawić pytanie, czy sztuczne warunki laboratoryjne bądź pytania ankietowe - główne narzędzia ekonomii behawioralnej - są naprawdę wiarygodnymi podstawami do wyciągania jakichkolwiek wniosków dotyczących zachowań człowieka w zwykłych warunkach. Niektórzy posuwają się do stwierdzenia, iż ekonomia behawioralna jest dziedziną badającą zachowania amerykańskich studentów potrzebujących drobnych na piwo.

W prawdziwym życiu rzadko bywamy całkowicie anonimowi - albo przynajmniej rzadko mamy taką pewność. Rzadko wchodzimy w interakcje jednorazowe. Zwykle mamy możliwość uczenia się, naprawiania błędów, negocjacji. Częstokroć stawki są wyższe niż kilka dolarów. 
Zastanówmy się nad wiarygodnością rezultatów gry „Dyktator”, w której - jak okazuje się w laboratorium - wielu badanych skłonnych STATYSTYCZNY jest podzielić się otrzymaną kwotą z zupełnie anonimowym partnerem, który nie ma żadnej szansy na odczucie i okazanie wdzięczności. Analogiczną sytuacją in vivo mogłaby być taka scena: idący chodnikiem człowiek zauważa banknot dwudziestodolarowy, podnosi go i zaczyna rozglądać się za jakimś nieznajomym, z którym mógłby się znaleziskiem podzielić. Coś tu nie gra?

A „Ultimatum”? Tak z ręką na sercu, gdyby nieznajomy (anonimowy!) człowiek, odziedziczywszy miliony, zaoferował wam skromne pięćdziesiąt tysięcy - odmówilibyście? Bo nie dał połowy? Na wszelki wypadek obwieszczam wszystkim potencjalnym spadkobiercom: przyjmę każdą sumę, jakkolwiek podział byłby nierówny!

Czy osoby badane w laboratorium nie czują się - no cóż - bada$n e$ ? Dzięki czemu mogą odczuwać nieuświadomioną (bądź wręcz uświadomioną) presję, jak na kozetce u psychoanalityka, by zaprezentować się z lepszej strony?

Pewnego razu przeprowadzono w Skandynawii badanie ankietowe: czy zapisałbyś/zapisałabyś się do organizacji ekologicznej (tu następowała specyfikacja), jeśli wpisowe wynosi tyle i tyle? Po zebraniu odpowiedzi, w drugiej części eksperymentu, osobom, które odpowiedziały twierdząco, przesłano... nie, już nie ankietę, ale deklarację członkowską wraz z druczkiem przelewu. Jaki ułamek deklarujących zgodę faktycznie wywiązał się z obietnicy postrzeganej początkowo jako hipotetyczna? No cóż, niewielki.

Nawet, jeśli osoby badane nie kłamią celowo, odpowiedzi na ankiety mogą się rozbiegać z rzeczywistością. Jak napisała poetka (Wisława Szymborska): „Tyle o sobie wiemy, na ile nas sprawdzono”. Właściwie osoby zajmujące się ekonomią behawioralną i tymi wszystkimi błędami poznawczymi, słabością woli i luką pomiędzy chłodnym myśleniem i gorącym działaniem winny doskonale zdawać sobie sprawę, że deklaracje hojności, szlachetności i wielkoduszności niekoniecznie muszą znaleźć przełożenie na działania w realnych sytuacjach, zwłaszcza gdy decyzje muszą być podejmowane szybko.

Kwestionowanie metod ekonomii behawioralnej nie ma bynajmniej na celu i nie jest równoznaczne $\mathrm{z}$ negowaniem stwierdzeń, które formułowane są w ramach tej dyscypliny. Większość $\mathrm{z}$ nich jest przecież - przynajmniej warunkowo, w pewnych okolicznościach - w sposób oczywisty prawdziwa. 
Nie trzeba gry „Dyktator”, by uznać, że wiele osób w różnych okolicznościach potrafi być zachwycająco szczodra i altruistyczna. Nie trzeba „Ultimatum”, by wiedzieć, że wielu z nas unosi się gniewem w obliczu niesprawiedliwego potraktowania siebie samego bądź innych i może zainwestować czas, wysiłki i środki w wymierzenie kary. Nie trzeba inwestować w kubki z nadrukiem, bo własne dzieci są zawsze najpiękniejsze, choć czasem trawa jest bardziej zielona po drugiej stronie płotu... Właściwie to czasem trudno uwierzyć w ten efekt posiadania: przynajmniej w Polsce mało kto wydaje się przekonany, że to, co sam ma, jest lepsze i ładniejsze od własności sąsiadów. Nie wspominając o stosach jeszcze zupełnie funkcjonalnych rzeczy, zalegających na śmietnikach, których właściciele pozbywają się chyba jednak nie z nadmiaru upodobania do rzeczy posiadanych.

Poza oczywistością jednych i kwestionowalności innych konstatacji ekonomii behawioralnej nie można też przeceniać ich zalet predykcyjnych. Zważywszy, że obserwowane efekty są zazwyczaj ograniczone do nawet jeśli przeważającej, to jednak tylko części populacji, trudno na tej podstawie formułować ogólne modele. Wydaje się, że zasadniczy wkład psychologii w nauki ekonomiczne był negatywny w tym sensie, iż podważył obowiązujący paradygmat modelowania podmiotów ekonomicznych jako jednostek racjonalnych, przewidujących i planujących długofalowo. Kolekcja ciekawych obserwacji - mniej lub bardziej wiarygodnych w odniesieniu do prawdziwego życia - nie wydaje się oferować spójnych ram do stworzenia formalizmu porównywalnego do aparatu matematycznego ekonomii neoklasycznej. Zbyt wiele tu wyjątków, przypadków specjalnych i różnorodności. $Z$ tego zresztą względu tak długo trzymano się nierealistycznego modelu homo oeconomicus. Z drugiej strony, nie można też zupełnie negować przydatności ekonomii behawioralnej zarówno w aspekcie naukowym, jak i w odniesieniu do życia codziennego jednostek. Nie wszyscy łapiemy się na to czy inne złudzenie poznawcze, nie wszyscy popełniamy wszelkie możliwe błędy. Ale znajomość katalogu tych najczęstszych $\mathrm{z}$ całą pewnością nie przeszkodzi w monitorowaniu własnych decyzji.

\section{Homo oeconomicus pogrzebany?}

„The report of my death was an exaggeration" (pogłoska o mojej śmierci była przesadzona), mógłby powiedzieć homo oeconomicus jak Mark Twain, gdy przeczytał w gazecie swój własny nekrolog. Mimo wszelkich enuncjacji rozkwit ekonomii behawioralnej i niemalże moda na popularne pozycje z tej dziedziny, „ekoni” wcale nie przeszli do 
lamusa. Wydaje się wręcz, że równolegle z popularnością autorów, takich jak Dan Ariely czy Richard Thaler, wzrasta też poczytność literatury typu „Freakonomia”, czy „Ekonomia miłości”, pozycji preSTATYSTYCZNY tendujących do ekonomizowania - w sposób mniej lub bardziej prymitywny - różnych aspektów ludzkich zachowań i dziedzin życia. Trend ten zastępuje lub uzupełnia nieco wcześniejszą fascynację socjobiologią. Prym w tym nurcie wiedzie (czy też wiódł) zmarły trzy lata temu, w 2014 roku, laureat Nagrody imienia Nobla z dziedziny ekonomii, Gary Becker. Uwiódł nawet Komitet Noblowski, który przyznanie nagrody uzasadnił „rozszerzeniem analizy ekonomicznej na szeroki zakres ludzkich zachowań i interakcji, wychodzących poza zachowania rynkowe" [Nobel Media 2014a].

Wydawałoby się, że ,przeciętny człowiek” z zadowoleniem przyjmie odwrót od odhumanizowanego wizerunku naszego gatunku, proponowanego przez socjobiologię i ekonomię neoklasyczną. Tymczasem oba te nurty zdobyły niezwykłą popularność w pewnych kręgach wykształconych laików, i to w zastosowaniu do dziedzin, do których praw nie uzurpowaliby sobie co bardziej zachowawczy przedstawiciele tych gałęzi nauki. Czy powoduje to dążenie do radykalizmu intelektualnego, pragnienie odcięcia się od humanistycznej czułostkowości $w$ tych brutalnych czasach czy też autentyczne przekonanie, że bogactwo (z zarazem chaos) życia ująć można w karby kilku prostych zasad? Czy wobec zjawisk, które we współczesnym (post?)nowoczesnym świecie wydawać się mogą anachroniczne, próbujemy zastosować „odczarowanie” (na wzór denettowskiego „odczarowania" religii), by poczuć się lepiej, nie potrafiąc im hołdować?

Niezależnie od tego, jaka jest prawda - w jakim stopniu homo jest oeconomicus - rozmaite postawy kulturowe i psychologiczne wobec tego pytania wydają się ciekawą kwestią socjologiczną i psychologiczną. Osobom z mniejszym zacięciem akademickim pozostaje cieszyć się życiem i starać się podejmować w miarę rozsądne decyzje ekonomiczne. Nie przesadnie, rzecz jasna. Sam Thaler, zapytany, w jaki sposób ma zamiar wydać otrzymane wraz z noblowskim medalem pieniądze, odparł: „Tak nieracjonalnie, jak to tylko możliwe” [Guardian 2017].

\section{Literatura}

Allais M., 1953, Le comportement de l'homme rationnel devant le risque: critique des postulats et axiomes de l'école Américaine, Econometrica, 21, s. 503-546.

Baumeister R.F., Tierney J., 2011, Willpower: Rediscovering the Greatest Human Strength, Penguin Press, New York.

Engel C., 2011, Dictator games: A meta study, Experimental Economics, 14(4), 583-610. 


$\begin{aligned} \text { ŚLASKI } & \\ \text { PRZEGLAD } & \text { Friedman M., 1953, Essays in Positive Economics, Chicago } \\ \text { STATYSTYCZNY } & \begin{array}{c}\text { Guardian, 2017, Nobel Prize in economics awarded to Richard Thaler, https://www. } \\ \text { Nr 16(22) }\end{array} \\ & \text { theguardian.com/world/2017/oct/09/nobel-prize-in-economics-richard-thaler (dostęp: } \\ & 5 \text { marca 2018). }\end{aligned}$

Güth W., Schmittberger R., Schwarze B., 1982, An experimental analysis of ultimatum bargaining, Journal of Economic Behavior \& Organization, 3(4), 367-388.

Ingram J.K., 1888, A History of Political Economy, Macmillan.

Kahneman D., Knetsch J.L., Thaler R.H., 1986a, Fairness and the assumptions of economics, Journal of Business, S285-S300.

Kahneman D., Knetsch J.L., Thaler R., 1986b, Fairness as a constraint on profit seeking: Entitlements in the market, The American Economic Review, 728-741.

Kahneman D., Knetsch J.L., Thaler R.H., 1990, Experimental tests of the endowment effect and the Coase theorem, Journal of Political Economy, 98(6), s. 1325-1348.

Kahneman D., Tversky A., 1979, Prospect theory: An analysis of decision under risk, Econometrica, XLVII (1979), s. 263-291.

Karp G., 2012, Profile: Richard Thaler, University of Chicago Booth School of Business professor, http://articles.chicagotribune.com/2012-04-30/business/ct-biz-0430-executive-profile-thaler-20120430_1_economics-daniel-kahneman-cost-fallacy (dostęp: 5 marca 2018).

Mill J.S., 1966, Zasady ekonomii politycznej, PWN, Warszawa.

Mischel W., 2014, The Marshmallow Test, Little, Brown, New York.

Nobel Media, 2014a, Gary S. Becker - Facts, http://www.nobelprize.org/nobel_prizes/ economic-sciences/laureates/1992/becker-facts.html (dostęp: 5 marca 2018).

Nobel Media, 2014b, Richard H. Thaler - Facts, http://www.nobel_prizes/economicsciences/laureates/2017/thaler-facts.html (dostęp: 5 marca 2018).

Thaler R., 1980, Toward a positive theory of consumer choice, Journal of Economic Behavior \& Organization, 1(1), s. 39-60.

Thaler R., 2013, Disclosures, http://faculty.chicagobooth.edu/Richard.Thaler/index. (dostęp: 5 marca 2018).

Thaler R.H., 2015, Misbehaving: The Story of Behavioral Economics.

Thaler R.H., Shefrin H.M., 1981, An economic theory of self-control, Journal of Political Economy, 89(2), s. 392-406.

Thaler R.H., Sunstein C.R., 1999, Nudge: Improving Decisions About Health, Wealth, And Happiness, CT Yales University Press. New Haven.

Weintraub E.R., 2002, Neoclassical Economics, http://www.econlib.org/library/Enc1/ NeoclassicalEconomics.html (dostęp: 5 marca 2018).

\title{
SANCTIONED IRRATIONALITY OR THE NOBEL PRIZE IN ECONOMICS FOR RICHARD THALER
}

\begin{abstract}
Behavioral economics is a sub-field of economics which questions the legitimacy of modeling the economic actor as Homo oeconomicus. Pointing out irrationality of human decisions, biases in our reasoning and loss-aversion, Kahneman and Tversky replaced the Expected Utility Theory with their Prospect Theory, giving rise to further investigations of humans' decision making. Richard Thaler, the winner of Nobel Memorial Prize in Economic Sciences in 2017, was recognized for his work on this field. Basing on experiments and surveys, he described some interesting effects, among them "endowment effect" and "mental accounting".
\end{abstract}

Keywords: Behavioral economics, irrationality, Prospect Theory, Richard Thaler. 